\title{
Mapping Uncertainty
}

The Collapse of Oyo and the Trans-Atlantic Slave Trade, $1816-1836$

\author{
Henry B. Lovejoy \\ University of Colorado, Boulder \\ hlovejoy@colorado.edu
}

\begin{abstract}
This historical GIS experiment attempts to map the collapse of the kingdom of Oyo alongside the departure of slave ships from the Bight of Benin. The achievements and drawbacks of mapping Africa's pre-colonial past require an overview of the sources and methods used to illustrate the dissolution and formation of inland places during an intense period of intra-African conflict. By collating geopolitical data, it is possible to represent on annual maps the likely origins and migrations of diverse groups of enslaved people who were involved in the warfare in the Bight of Benin hinterland between 1816 and 1836 . During this period, an unknown number of captives were enslaved and forced into an internal slave trade, most especially into the Sokoto Caliphate, while over 75,00o individuals involuntarily boarded European slave ships leaving for Brazil, Cuba and, due to British abolition efforts, Sierra Leone.
\end{abstract}

\section{Keywords}

African diaspora - trans-Atlantic slave trade - Collapse of Oyo - Sokoto Caliphate Bight of Benin - Yoruba diaspora - West African historical GIS

Much of pre-colonial sub-Saharan West Africa lacks detailed, reliable historical maps depicting inland towns and political boundaries during the era of the trans-Atlantic slave trade. One solution to this problem involves extracting geo-historical data pertaining to inland Africa from available primary and secondary sources and entering them into spreadsheets designed to function with Quantum Geographical Information System (QGIS). The use of the QGIS TimeManager plugin enables yearly plotting of the dissolution and formation of dozens of towns in the Bight of Benin hinterland during the jihād and wars 
associated with the collapse of the kingdom of Oyo. ${ }^{1}$ This mapping experiment also integrates data obtained from Voyages: The Trans-Atlantic Slave Trade Database related to the migration of nearly 75,00o people, the majority of whom were Yoruba-speakers who boarded slave ships at ports between Little Popo and Lagos between 1816 and $1836 .^{2}$ The annual maps illustrate internal zones of conflict to demonstrate when and where enslaved Africans came from inland before boarding slave ships to Brazil, Cuba and Sierra Leone. These geopolitical data have resulted in a series of twenty-one maps related to Oyo's collapse and coastal slaving activity, which are published as supplementary files (https://doi.org/10.6084/mg.figshare.7976978), ${ }^{3}$ along with an animated map (https://doi.org/10.6084/mg.figshare.7977047).

Mapping the uncertainty of Africa's internal geography using historical GIS techniques makes possible a visualization of the ebb and flow of pre-colonial boundaries, as well as the formation of diasporas, onto a series of maps. ${ }^{4}$ The evolving methodology of this experiment arises from data collected for a map plotted with hundreds of toponyms related to the kingdom of Oyo at its greatest extent and its immediate neighbors in c. 1780. This earlier quantitative spatial history project identifies how secondary source maps of pre-colonial, sub-Saharan African history are "thematically, spatially and temporally fragmented." But by amassing GIS-operable data from extant sources, such maps can "be 'defragmented' and made into a digital atlas plotted along a temporal

1 QGIS. http://www.qgis.org/en/site/index.html (Accessed since 2014); and "QG IS Time Manger Plugin." https://plugins.qgis.org/plugins/timemanager/ (Accessed since 2014).

2 David Eltis, dir. Voyages: The Trans-Atlantic Slave Trade Database. http://slavevoyages.org. (Accessed 2018).

3 High resolution versions of the maps referred to in this article are available via this link.

4 The secondary literature related to mapping uncertainty is extensive, but some examples include: Jingxiong Zhang and Mike Goodchild, Uncertainty in Geographical Information (New York: Taylor and Francis, 2002); André Skupin and Sara Irina Fabrikant, "Spatialization Methods: A Cartographic Research Agenda for Non-geographic Information Visualization," Cartography and Geographic Information Science 30 (2) (2003): 95-115; Peter Doorn, "A Spatial Turn in History," GIM International (2005): online. https://www.gim-international.com/content/ article/a-spatial-turn-in-history (Accessed 2016); Anne Kelly Knowles, "Emerging trends in historical GIS," Historical Geography 33 (2005): 7-13; Ian N. Gregory and Paul S. Ell, Historical GIS: Technologies, Methodologies and Scholarship (Cambridge: Cambridge University Press, 2007); David J. Bodenhamer, John Corrigan and Trevor M. Harris, eds., The Spatial Humanities: GIS and the Future of Humanities Scholarship (Bloomington: Indiana University Press, 2010); Onno Boonstra, "Barriers Between Historical GIS and Historical Scholarship," International Journal of Humanities and Arts Computing 3 (1-2) (2010): 3-7; Jordi Martí-Henneberg, "Geographical Information Systems and the Study of History," Journal of Interdisciplinary History 42 (1) (2011): 1-13; Mark Palmer, "Theorizing Indigital Geographic Information Networks," Cartographica 47 (2) (2012): 80-91; Alexander Von Lünen and Charles Travis, eds., History and GIS: Epistemologies, Considerations and Reflections (Dordrecht: Springer, 2013). 
axis." 5 To map out a single region year-by-year has involved ingesting the names and coordinates of pre-colonial cities, towns and villages into a spreadsheet, while taking note of the key years of conflict in relation to the destruction and establishment of these places.

Before explaining the maps published in conjunction with this article, it is necessary to offer an upfront and honest critique regarding these annual visualizations. Anne Kelly Knowles points out how digital tools can "reveal relational patterns, including spatial patterns, in new ways that can be very stimulating ... [but we] should resist the seductive impression that the images generated by computer programs are real." Knowles also cautions that any attempt to map historical geography is "a jarring experience [because] the process of trying to map historical information reveals how uncertain, vague, imprecise, or temporally unstable locations can be."7 After all, primary sources related to Oyo's collapse will always be inexact due to the limitations of the primary sources, both oral and written, which contain sporadic and incomplete references to specific dates, locations and conflict. The secondary sources, which include interpretations of the available primary sources, also involve complex debates over the chronology of conflicts and the subsequent transformations to the geo-political landscape.

Within this scope of an immeasurable amount of missing data, the maps presented herein must always be treated as approximations because of inexact and missing data, limitations in software functionality and any errors of interpretation of the sources. With this heavy caveat in mind, the representations that the maps portray still have degrees of validity as an interpretive tool to rethink the history of Africa and the African diaspora. Chad Gaffield argues that "digitally enabled historical research offers many possibilities for probing change over time at diverse scales that need not be fully determined in advance." ${ }^{8}$ This mapmaking initiative therefore puts caution aside at the risk of displaying data that have misrepresentations, yet clearly have associations between the backdrop of localized conflict in Africa and the internal and external slave trades. In order to draw a series of annual maps for one quadrant of

5 Henry B. Lovejoy, "Redrawing Historical Maps of the Bight of Benin Hinterland, c. 178o," Canadian Journal of African Studies 47 (3) (2013): 443-463.

6 Anne Kelly Knowles, "Why We Must Make Maps: Historical Geography as a Visual Craft," Historical Geography 42 (2014): 24.

7 Anne Kelly Knowles, "Historical Geographic Information Systems and Social Science History," Social Science History 40 (4) (2016): 747.

8 Chad Gaffield, "Map Quests: Scaling the Past in the Digital Age," Perspectives on History (2016), online. https://www.historians.org/publications-and-directories/perspectives-on-history/ october-2016/map-quests-scaling-the-past-in-the-digital-age. (Accessed December 2016). 


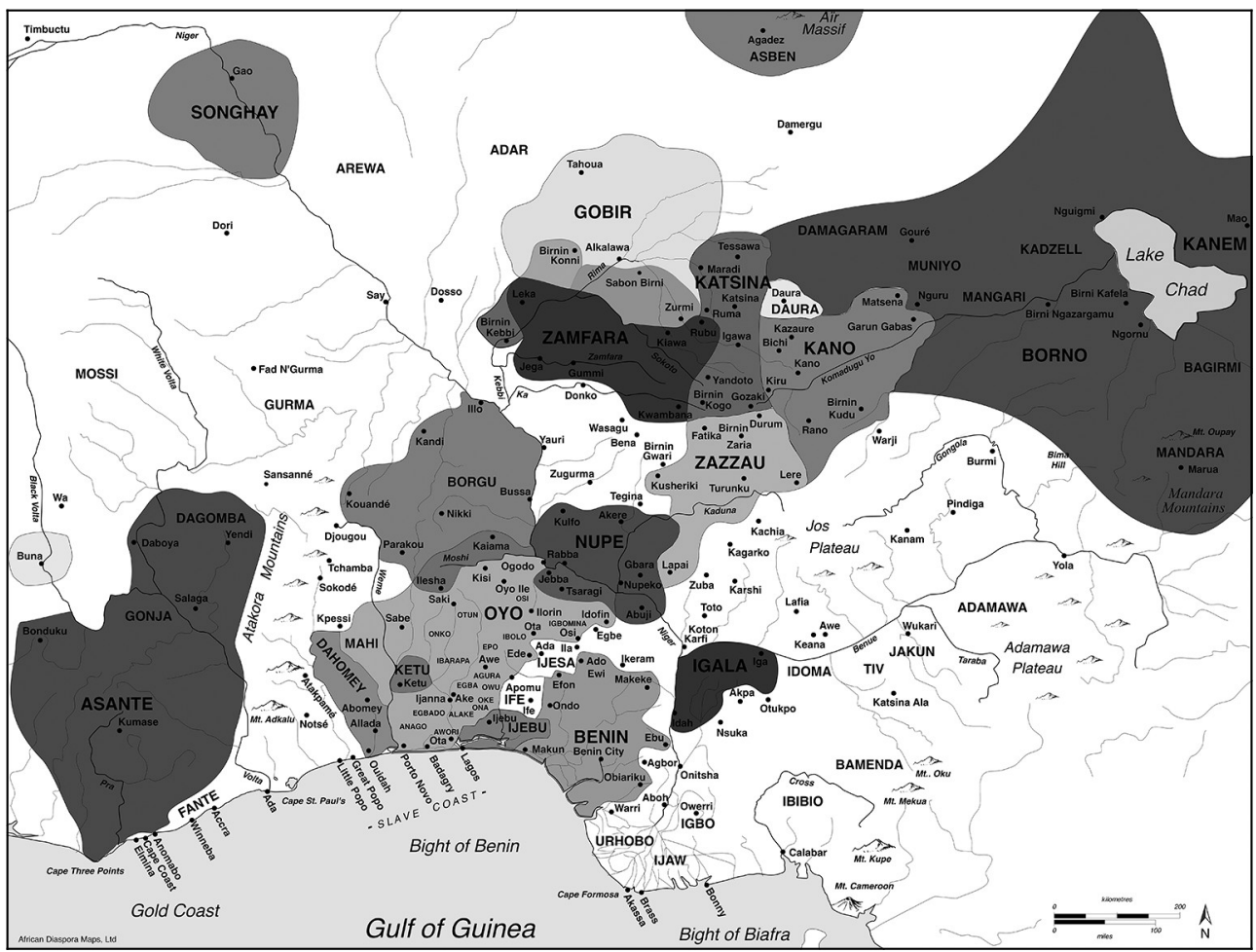

FIGURE 1 Bight of Benin and Central Bilād al-Sūdān, 1800

HENRY B. LOVEJOY, AFRICAN DIASPORA MAPS LTD., 2019

the African continent over a twenty-one year period, I have extrapolated and manipulated a set of conflict data from a key selection of primary and secondary sources to function with QGIS. Beyond explaining the methods, this article also includes an annual summary of conflict apropos the displacement of tens of thousands of individuals into the Atlantic slave trade between 1816 and 1836 .

At the start of this experiment, I sought to better understand using before-andafter maps the geo-political transformation surrounding the collapse of Oyo, the expansion of the Sokoto Caliphate and the Yoruba diaspora (Maps 1-2). ${ }^{9}$

9 Paul E. Lovejoy, Jihād in West Africa during the Age of Revolutions (Athens: Ohio University 


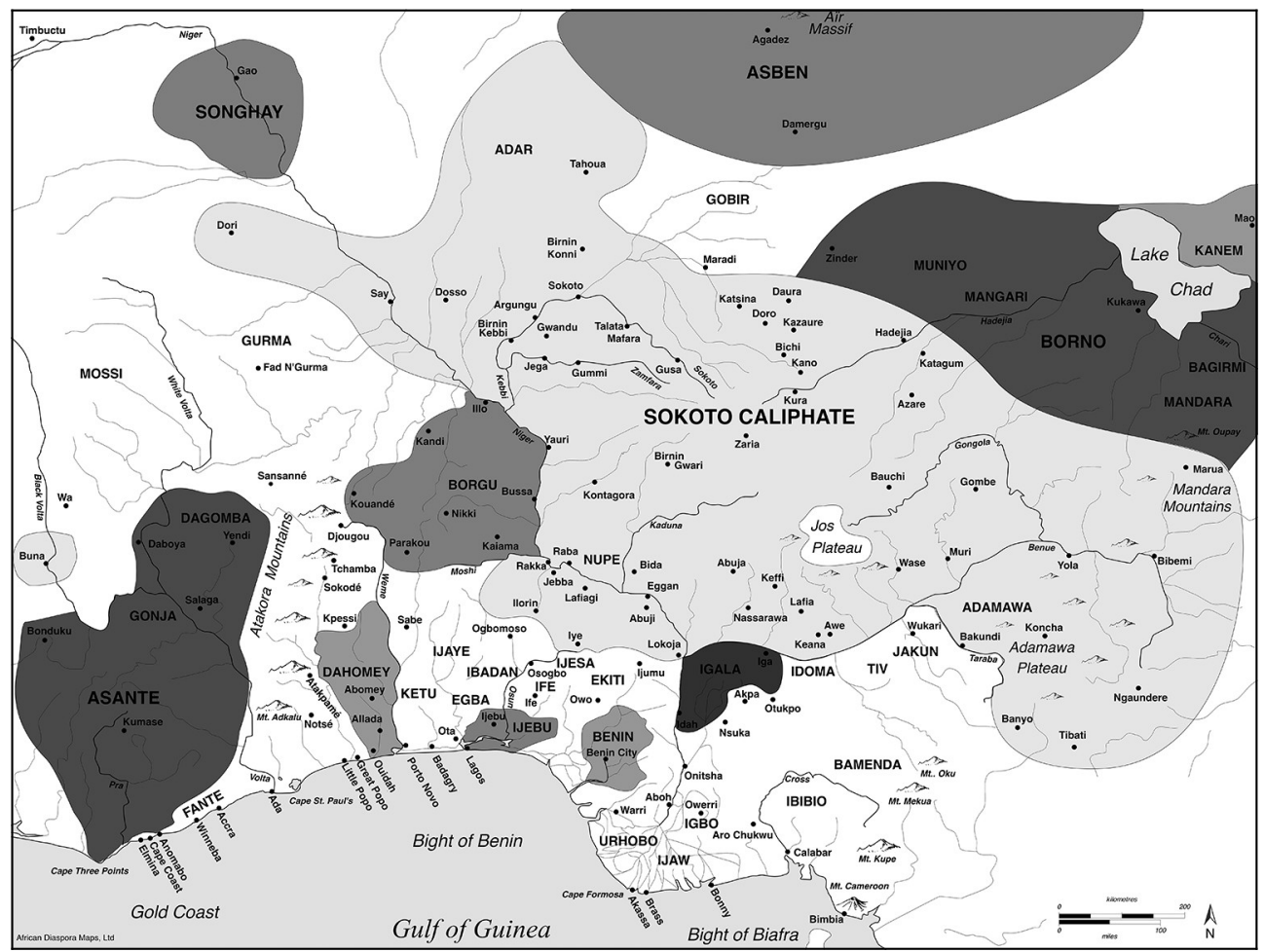

FIGURE 2 Sokoto Caliphate, Borno and Bight of Benin, 1840 HENRY B. LOVEJOY, AFRICAN DIASPORA MAPS LTD., 2019

The modern-day region under analysis centers on the Yoruba-speaking ethnolinguistic group in what is now southwestern Nigeria, as well as parts of Benin and Togo. Historically, Oyo was one of the largest political entities engaged in the Atlantic slave trade at the Bight of Benin leading up until the kingdom's decline by 1836 . Over the course of Oyo's pre-nineteenth century expansion, other kingdoms and confederacies owed direct allegiance to the kingdom, while its rivals opposed its hegemony over the region. Allegiances and opposition shifted over time until eventually the kingdom of Oyo gradually collapsed because of a complex series of events influenced by both internal and external factors.

Press, 2016), 70-71. These before-and-after maps build upon "States of the Guinea Forest and Savanna, XVIIth to xIxth Centuries" and "The States of the Sudan in the XIxth Century" in J.D. Fage, An Atlas of African History (London: Edward Arnold Ltd, 1958), 32 and 39. 


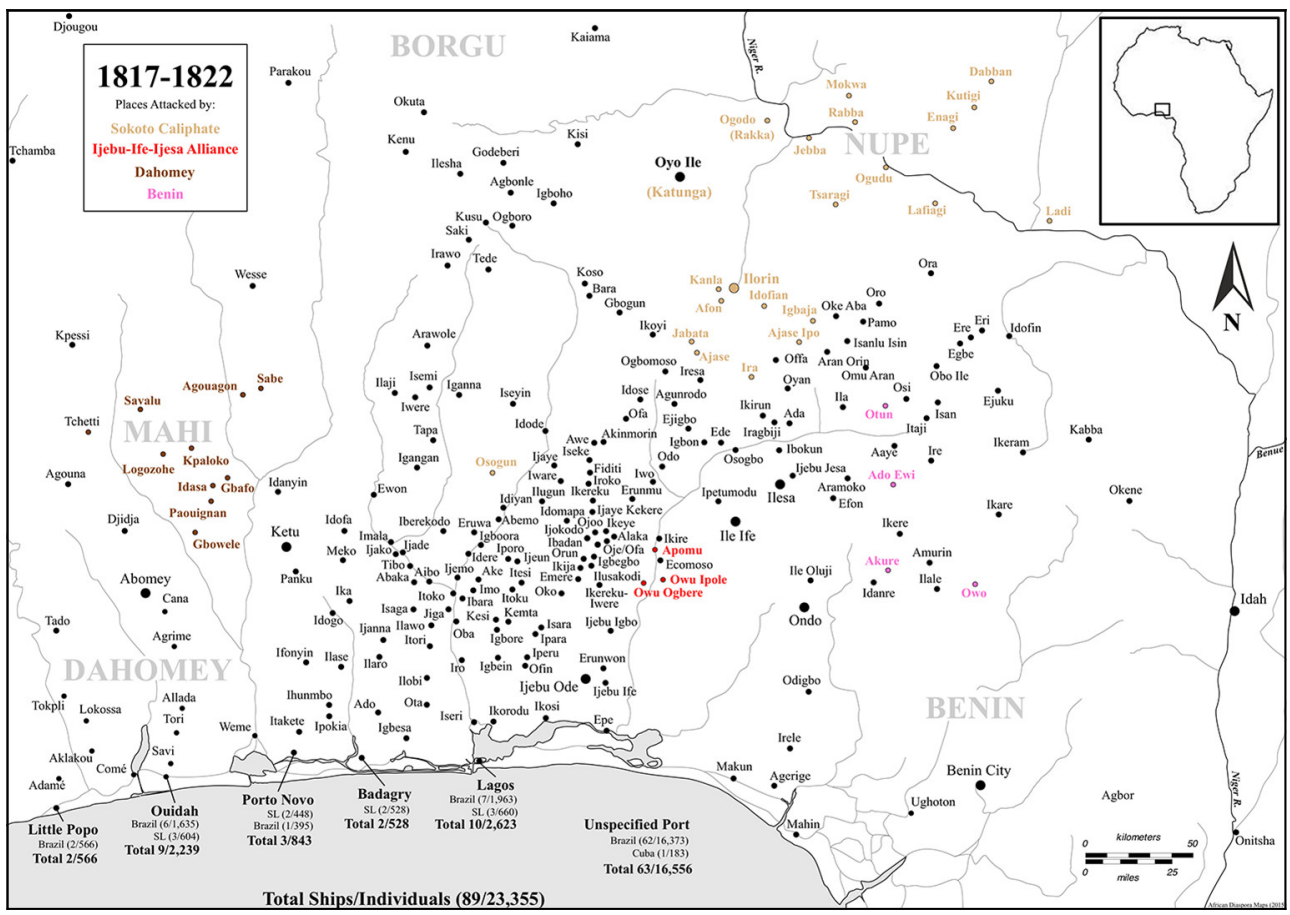

FIGURE 3 The Ascension of Ilorin and Owu Wars, 1817-1822 HENRY B. LOVEJOY, AFRICAN DIASPORA MAPS LTD., 2019

The basic data for this West Africa historical GIs project derives from a list of towns I generated in compiling a map entitled "Oyo at its greatest extent in c. 1780."10 The preliminary data for this map included a two-column spreadsheet of toponyms and their respective political affiliations. To begin to visualize Oyo's collapse, I consulted with Olatunji Ojo to construct three maps presented in 5-7 year periods, while also adding in documented slave ship departures on a port-by-port basis (Maps $3-5){ }^{11}$ In order to generate more meaningful geo-referenceable data designed to operate with the QGIS TimeManager plugin, I consulted with Marcel Fortin, Head of the Map and Data Library, and Byron Moldofsky, Director of the Cartography Office, at the University of Toronto. Under their tutelage, I then developed the historical base map for the Bight of Benin hinterland using the WGS84/Pseudo Mercator coordinate reference system and open-source vector data from Natural Earth and DIVAGIS. ${ }^{12}$ Due to major and recent changes to Africa's physical geography, I manu-

\footnotetext{
10 H. Lovejoy, "Redrawing," 444.

11 I initially presented these maps at the African Studies Annual Meeting in San Diego, 2015.

12 "Downloads," Natural Earth. http://www.naturalearthdata.com/downloads/ (Accessed
} 


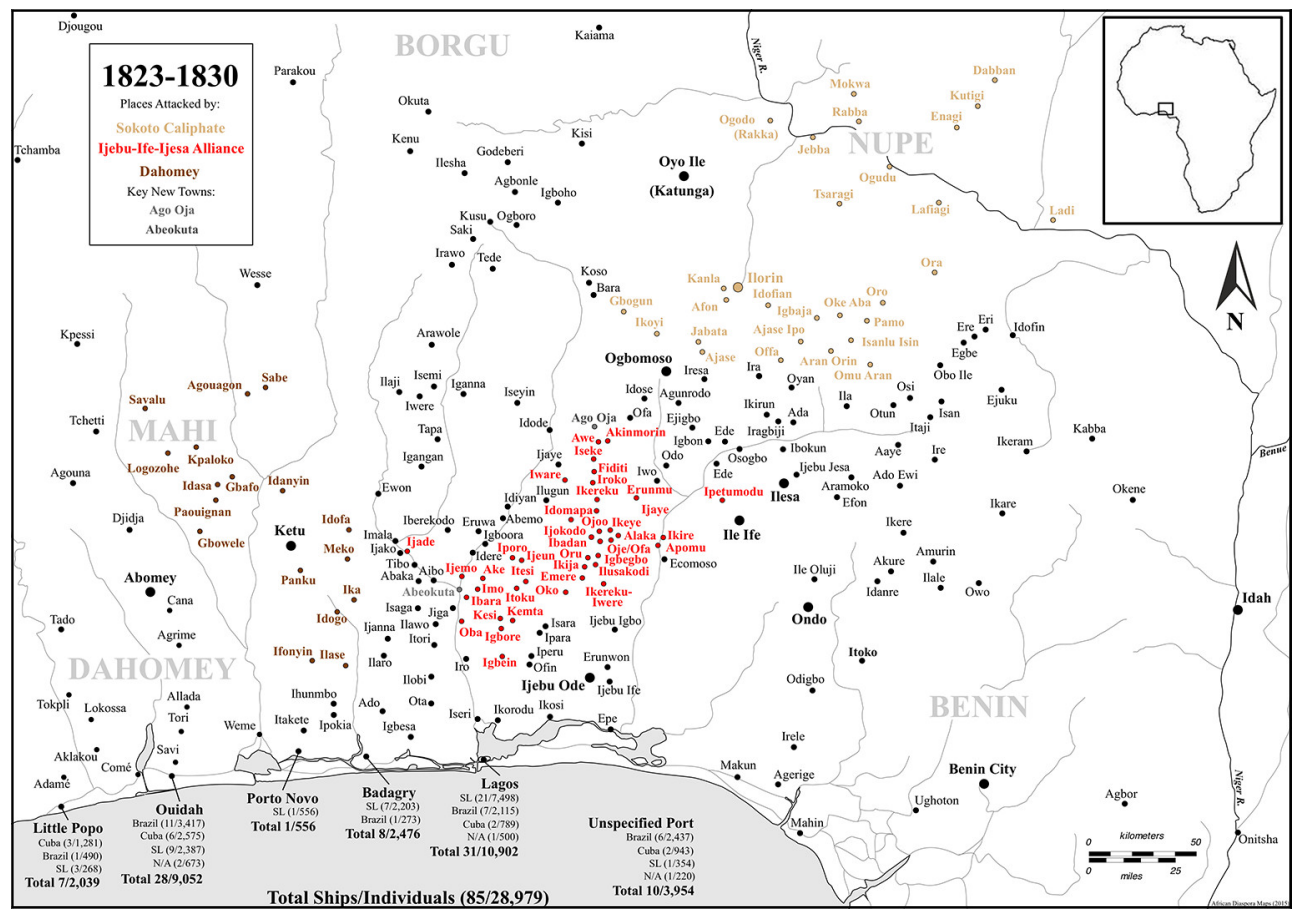

FIGURE 4 The Egba Crisis, 1823-1830

HENRY B. LOVEJOY, AFRICAN DIASPORA MAPS LTD., 2019

ally deleted any man-made lakes, such as the Kainji Reservoir and Lake Volta, which formed after the damming of rivers in the twentieth century. Additionally, I isolated and emphasized major rivers relevant to historical inland trade routes and presumed pre-colonial political borders. In order for the toponym labels of dozens of towns to appear legibly, I used a 1:700,000 scale.

For operability with the TimeManager plugin, I added $\mathrm{X}$ and $\mathrm{Y}$ coordinates, as well as "start" and "end" dates relative to varying levels of conflict by city, town or village. Since this project involved not much more than plotting a dot on a map, I ascertained coordinates with the QGIS OpenStreetMap plugin by hovering the mouse over positions where a place still exists today, or if it were destroyed, where it might have been according to other secondary source maps obtained from the historiography. Creating "start" and "end" dates for conflict at each place involved researching primary and secondary sources. Collating

2014); "Download Data by Country," DIVA-GIS. http://www.diva-gis.org/gdata (Accessed 2014). Inland water vector data downloaded for the countries of Nigeria, Benin, Togo, Burkina Faso and Chad. 


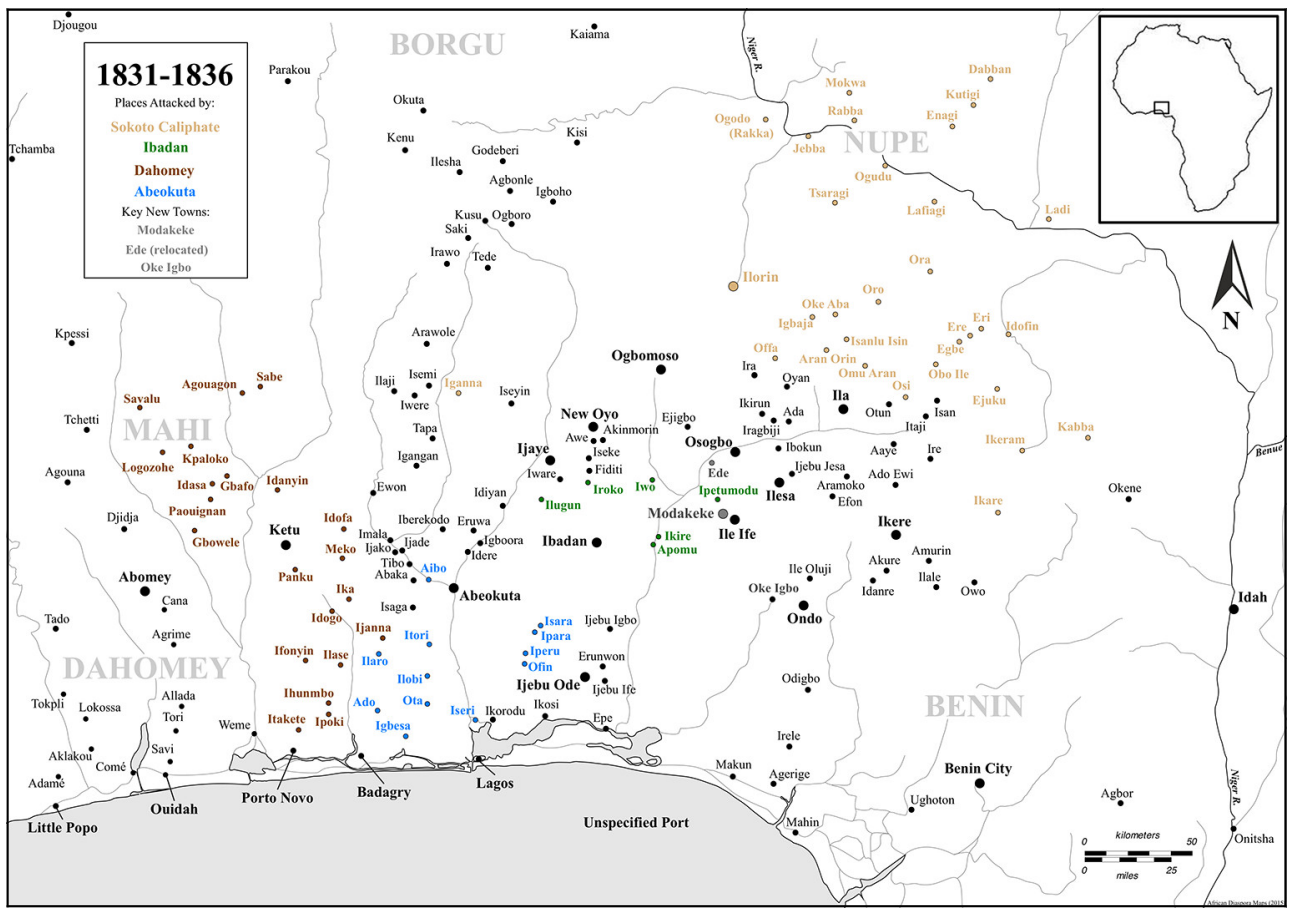

FIGURE 5 Oyo's Final Years, $1831-1836$

HENRY B. LOVEJOY, AFRICAN DIASPORA MAPS LTD., 2019

conflict data for pre-colonial, sub-Saharan Africa is inherently problematic because of missing data and a scarcity of contemporary sources. Moreover, the TimeManager plugin requires a yyyy-mm-dd format to function properly, although the historical evidence might provide enough clues to approximate years, yet the sources rarely, if ever, contain a level of detail to specify conflict in terms of months and days. Due to the software restrictions and much experimentation through trial and error, I used 2 January to reflect the start of a new year and $3_{1}$ December to mark the end of year. These days and months obviously carry zero historical value.

In order to reflect conflict in a spreadsheet, I added a new row for each instance of when and where conflict likely occurred. Table 1 demonstrates conflict data for the capital city of Oyo, which was attacked by Ilorin a number of times from 1817 until its final destruction in 1836 . The sequence of dates for the same town at the same coordinates reflects different moments of conflict, while noting how the meaningless months and days have no historical value, but were required for operability with the TimeManager plugin. The "Category" column is indicative of other political affiliations involved in the conflict. The change in 
TABLE 1 Conflict data for the capital city of Oyo, 1816-1836

\begin{tabular}{|c|c|c|c|c|c|c|}
\hline Date 1 & Date 2 & Town & Category & $X$ & $\mathrm{Y}$ & CI \\
\hline 1816-о1-02 & $1816-12-31$ & Оуо & Oyo & 478743 & $100235^{8}$ & $\mathrm{O}$ \\
\hline 1817-01-O2 & $1817-12-31$ & Оуо & Ilorin & 478743 & $100235^{8}$ & 1 \\
\hline 1818-01-02 & $1820-12-31$ & Оуо & Oyo & 478743 & $100235^{8}$ & $\mathrm{O}$ \\
\hline 1821-01-02 & $1821-12-31$ & Oyo & Ilorin & 478743 & $100235^{8}$ & 1 \\
\hline 1822-O1-O2 & $1830-12-31$ & Oyo & Oyo & 478743 & $100235^{8}$ & O \\
\hline 1831-01-02 & $1832-12-31$ & Oyo & Ilorin & 478743 & $100235^{8}$ & 1 \\
\hline 1833-01-02 & $1834-12-31$ & Oyo & Oyo & 478743 & $100235^{8}$ & O \\
\hline $1835^{-01-02}$ & $1835^{-12-31}$ & Oyo & Ilorin & 478743 & $100235^{8}$ & 2 \\
\hline $1836-01-02$ & $1836-12-31$ & Oyo & New Oyo & 436718 & 877789 & 9 \\
\hline
\end{tabular}

coordinates in the last row demonstrates the abandonment and resettlement of people from what is known today as "Old Oyo" to "New Oyo." The data collection process occurred for dozens of different towns, each with its own specific chronologies of conflict. For this experiment, the toponym spreadsheet now contains over 700 rows for dozens of places.

The column labeled "CI" stands for "conflict intensity," which provides a basic, albeit subjective numerical scale related to the degrees of conflict. Accordingly, "o" represents "no conflict;" " 1 " equals "some conflict," " 2 " reflects "the destruction of a place" and " 9 " indicates "the formation of a new town." Presenting conflict as a numerical value enables cartographic visualizations, whereby a black dot shows zero conflict, a red dot indicates some conflict, a red triangle implies the destruction of a place and a yellow star illustrates the foundation of a new town. In the event the conflict intensity scale demands more complexity, I deliberately left numbers 3 through 8 open for future analysis. The decision to integrate a conflict intensity scale arose through collaborations with Eric Vance, director of the Laboratory of Interdisciplinary Statistical Analysis, and Zachary Mullen and Ashton Wiens, graduate students in Applied Math at the University of Colorado, Boulder. ${ }^{13}$

Drawing boundaries of pre-colonial African states is methodologically problematic. ${ }^{14}$ Anne Kelly Knowles and Amy Hillier argue that mapping historical

13 In the fall of 2017, the Center to Advance Research and Teaching in the Social Sciences at the University of California Boulder awarded Henry Lovejoy and Eric Vance a seed grant to explore geo-historical data with statistical analysis.

The time-consuming process of drawing polygons occurs within QGIS. The lines of the 
uncertainties with GIS "reinforce the naïve acceptance of maps as authoritative statements because the software so swiftly produces maps behind whose veneer of professionalism may lie all manners of unseemliness." ${ }^{15}$ In his political maps of Oyo, Robin Law recognizes how "precise boundaries are not in every case easy to fix. Indeed, the very concept of a linear frontier may not always be applicable."16 As a result, the maps in this article integrate the concept of "fuzzy boundaries" as a method in which to illustrate unclear political lines. Despite high degrees of uncertainty, political boundaries illustrate a selection of major states pertinent to the focus of this experiment, including: Oyo (pink), Ilorin (yellow), Dahomey (green), Ijebu (blue), Badagry (peach), Ibadan (brown) and Abeokuta (grey).

Data from Voyages: The Trans-Atlantic Slave Trade Database illustrates the number of slave ships leaving the Bight of Benin on an annual basis. Whenever available, I assigned each ship an X and Y coordinate to appear beneath a port of embarkation. If the port of departure was not documented, I designated those ships as leaving from an "unspecified port." The labels for each ship include the Voyages resource identifier (grey), as well as totals or estimates for the number of people on board each vessel (black). I used an svG file of a ship to represent different destinations, i.e. Brazil (green), Cuba (red), Sierra Leone (black) and places in the United States and elsewhere in the Caribbean (peach). To reflect missing shipping data, each map includes annual totals for both documented embarkations and estimated departures.

While the Roman calendar works well for plotting shipping data, the military campaigns in the Bight of Benin interior typically occurred in the dry season due to the challenges of moving armies during the wet season. This temporal framework immediately raises issues as to whether or not the Roman calendar is an appropriate method for plotting conflict data on an annual basis. Often incomplete shipping data provides not much more than the year of the voyage, but rarely a month and/or day of departure off the coast of Africa. Aligning annual shipping data with the dry season, which spans between December and April, might not be possible due to the uncertainty of which month in the year the ship might have departed.

Shipping data provides the best totals for quantifying the annual departures of 75,0oo people to Brazil, Cuba and Sierra Leone. Unfortunately, annual esti-

annual shapes overlap with one another and can only be modified when the "TimeManager" plugin is turned off.

15 Anne Kelly Knowles and Amy Hillier, eds., Placing History: How Maps, Spatial Data and gIs Are Changing Historical Scholarship (Redland: ESRI Press, 2008), 19.

16 Robin Law, The Oyo Empire, c. 160o-c. 1836: A West African Imperialism in the Era of the Atlantic Slave Trade (Brookfield: Gregg Revivals, [1977] 1991), 85. 
mates for the internal slave related to Oyo's collapse do not exist between 1816 and 1836. However, it is known that the Sokoto Caliphate had large populations of enslaved people, many of whom would have come from Oyo territory and its environs. Once Ilorin, an important town in Oyo territory, became an emirate within the caliphate in 1823 , the scale of the internal slave trade must have equalled, but more likely surpassed the total number of individuals who boarded slave ships at the coast during this period.

\section{The Annual Maps of Oyo's Collapse}

The remainder of this article outlines conflicts plotted on to the annual maps by citing key excerpts from both primary and secondary sources, along with documented departures and estimates from Voyages. Each map is named according to the respective year and these brief explanations serve as a guide to explain the major changes depicted on the maps over time.

The key primary sources from which these data derive require further explanation due to historical uncertainties. In some cases, transient European explorers witnessed warfare at places without fully understanding the local or regional context. Otherwise, missionaries recorded the experiences of enslavement for Africans several years after they boarded slave ships and were liberated in British abolition efforts in Sierra Leone. This small selection of written contemporary sources can of course be supplemented with oral traditions, but verbal recollections are often difficult to date with any precision, or to crossreference with the documentation. Shipping data appear to be much more reliable, but it too contains gaps oftentimes surrounding the arrival and departure dates, and at other times, ports of embarkation were unspecified in the documentation. As the scholarship cited herein has long proven, many people were transported to the Americas from places in and around Oyo during the period of intense conflict after 1816, but from where and when exactly, and in what numbers, remains more obscure, especially in consideration of the internal slave trade. Moreover, not all people leaving the Bight of Benin were enslaved through warfare in this period, but via historical trade routes and networks.

The key primary sources used in this study derive from the observations of foreign diplomats and former slaves educated by Protestant missionaries. Hugh Clapperton, a British diplomat, traveled from Badagry through the Oyo capital in $1825^{-1826}$ and onto Sokoto where he died in $1827 \cdot{ }^{17}$ Clapperton's journal

17 Jamie Bruce Lockhart and Paul E. Lovejoy, eds., Hugh Clapperton Into the Interior of Africa: Records of the Second Expedition, 1825-1827 (Leiden: Koninklijke Brill, [1829] 2005). 
survived because his servant, Richard Lander who also wrote about his experiences, returned back south through Oyo to Badagry after Clapperton's death. ${ }^{18}$ In 1830, Richard Lander, along with his brother John, traveled inland again from Badagry to Bussa in Borgu and then down the Niger in order to map the course of the river to the delta. ${ }^{19}$ Otherwise, the narratives of Samuel Ajayi Crowther of Oyo, Joseph Wright of the Egba and Osifekunde of Ijebu provide firsthand accounts of enslavement in the 1820s, including references to the destruction of many towns and shifting trade routes in high conflict zones. ${ }^{20}$ Another key source is Samuel Johnson, whose parents were from Oyo and were taken to Freetown in British campaigns to blockade the slave trade. Born in Sierra Leone, Johnson was educated by the Church Missionary Society, and as a missionary, he returned to the Bight of Benin hinterland where he subsequently recorded Oyo oral traditions. By 1897 , he had completed a work documenting the history of the Yoruba states, including accounts related to the destruction of towns. ${ }^{21}$ Other missionaries, such as Edward Irving, recorded more information in Ijebu territory in the 185 os, especially in relation to the destruction of many Egba towns. ${ }^{22}$ A French abbot, Thomas Mouléro, provided a list of annual campaigns of King Gezo of Dahomey between 1818 and $1857 .{ }^{23}$

18 Richard Lander, Records of Captain Clapperton's Last Expedition to Africa, 2 vols. (London: Colburn and Bentley, 1830).

19 Richard Lander and John Lander, Journal of an Expedition to Explore the Course and Termination of the Niger, 2 vols. (London: John Murray, 1832).

20 J.F. Ade Ajayi, "Samuel Ajayi Crowther of Oyo," in Philip Curtin, ed., Africa Remembered: Narratives by West Africans from the Era of the Slave Trade (Madison: University of Wisconsin Press, 1967), 289-316; Philip Curtin, "Joseph Wright of the Egba," in Curtin, ed., Africa Remembered, 318-320; Peter C. Lloyd, "Osifekunde of Ijebu," in Curtin, ed., Africa Remembered, $217-288$.

21 Samuel Johnson, The History of the Yorùbás from the Earliest Times to the Beginning of the British Protectorate (London: Routledge \& Sons Limited, 1921).

22 Edward Irving, "Ijebu Country," Church Missionary Intelligencer 7 (1856): 65-72, 93-98 and 118-120.

23 Thomas Mouléro, “Guézo ou Guédizo Massigbé," Etudes dahoméennes 4 (5) (1965): 52-53. Mouléro notes that Gezo "made other wars which are not mentioned [in this list]" (52 n. 2). Redacted from an email with Robin Law, 23 June 2018. Sections of the list for 18351851 can be found in A. Le Herissé, L'ancien royaume de Dahomey (Paris: E. Larose, 1911), 323; and Paul Hazoumé, Doguicimi (Paris: Maisonneuve et Larose, [1938] 1978). Hazoumé's novel is based on a profound knowledge of Dahomey traditions. At the beginning of the story, Gezo was praised as the "conqueror of Glito, Chèlèti, and Logozohè" (p. 23). These places correspond to Mouléro's list for 1818-1820. The novel also mentions the "defeat at Hounjroto" (p. 176), which is recorded in Mouléro's list for an unsuccessful war against Houndjroto in 1821. A subsequent passage lists four campaigns in the seventh to eleventh years of Gezo's reigns (p. 405), which also conform to Mouléro's list from 1824 until 1828 . 
And finally, Voyages and Liberated Africans data allow projections on the numbers of people boarding slave ships, especially at ports between Little Popo and Lagos. $^{24}$

The turbulent era surrounding Oyo's collapse is mappable through the extraction of geo-referenceable data, mostly from the secondary literature which extensively analyzes the key primary sources listed above. The sequential maps presented here begin in 1816, a year before a Muslim slave uprising at Ilorin in 1817 challenged the stability of the Oyo state. ${ }^{25}$ This slave uprising, which was inspired by the jihād emanating from the Sokoto Caliphate, triggered a constitutional crisis and severely weakened Oyo's control over the region. In 1804, the political landscape among the Hausa states underwent major geopolitical transformations, whereby Uthmān dan Fodio, who along with his brother, 'Abdullahi dan Fodio, and his son, Muhammad Bello, overthrew the established governments of the Hausa states, as well as Borno and Nupe.

At this time, Oyo was already under pressure because of competition for the trade in slaves to the coast for sale into the trans-Atlantic trade. In c. 1807, Dahomey raids on Oyo's principal port at Porto Novo had forced Oyo traders to sell slaves to Ife merchants in the market town of Apomu, located close to the Osun River. This shift in commercial activity led to conflict with Ijebu, whose merchants were kidnapping Oyo citizens and otherwise interfering with Oyo traders at Apomu. Ijebu merchants took slaves from the interior to the northern side of Lagos lagoon before sending them to ships moored off the coast. Over the next several years, Oyo sought to establish stability in the area by suppressing raiding and protecting its merchants, but this only provoked war with Ife and the subjection of a number of western Ife towns by Oyo's ally, Owu. ${ }^{26}$

The following sub-sections attempt to organize and explain the ensuing conflicts that occurred in and around Oyo starting a year before the Muslim slave uprising and ending in the year the capital city of Oyo was abandoned in 1836 .

2.1

Map of 1816 (https://doi.org/10.6084/m9.figshare.7976978)

Despite the troubles around Apomu and the spread of jihâd in the north, the kingdom of Oyo maintained control over its well-established trade routes. According to Folayan:

24 Eltis, Voyages; and Henry B. Lovejoy, dir., Liberated Africans. http://liberatedafricans.org/. (Accessed 2018). These data mostly derive from extensive collections of archival sources located around the Atlantic world.

25 P. Lovejoy, Jihād in West Africa, ch. 3.

26 Law, Oyo Empire, 219-224. 
One of the old routes linking Old Oyo with the Coast passed through the northern Egbado town of Meko ... connecting Old Oyo with Ketu and thence with the coast at Porto Novo, a port which continued to serve as the outlet for Oyo .... Besides the northern Egbado route there was another one which linked Central and Southern Egbado with Oyo. Its southern terminus was also Porto Novo from where the route entered Southern Egbado either through Igbeji or Ipokia. Crossing the Yewa or Ado river the trade route then entered Central Egbado through Ilaro and Ijanna ... with the slaves selling for about $£_{3}$ to $£_{4}$ per head. The trade route now passed out of Egbadoland through Igan or Ilogun to Iseyin, Shaki, Igboho, Kishi and thence to Oyo. From Oyo this same route continued through Raba on the Niger to Kano, the famous emporium of the Sudan. ${ }^{27}$

While Dahomey had been tributary to Oyo since the early eighteenth century, that status came into question once Gezo became ruler of Dahomey in 1818 and ended in 1823. The Dahomey boundaries are reflected in the slightly darker shading of pink on the map. Ijebu never owed allegiance to Oyo, as represented by blue boundaries.

In 1816, sixteen documented slave ships left the coast, the majority of which went to Brazil, from mostly unidentified ports of embarkation. There were another three ships that the British seized and took to Sierra Leone and two others destined for Cuba. They left from Ouidah or Little Popo. The total number of known embarkations was 4,205 individuals, while estimates for all ships suggest there were more than 12,00o people leaving in this year mostly via Oyo trade routes, which was among the highest totals leaving the Bight of Benin in this study.

\subsection{Map of 1817 (https://doi.org/10.6o84/m9.figshare.7976978)}

This year marks the start of the protracted decline of Oyo, which began with the Muslim slave uprising in Ilorin. In 1817, Afonja, the commander-in-chief of Oyo's provincial military at Ilorin, had ambitions of taking the throne from Alafin Majutu, who reigned in Oyo from 1802 to 1831. Afonja provoked a Muslim rebellion in the large, provincial military based at Ilorin, which Robin Law has argued "greatly increased the intensity and territorial extent of the distur-

27 Kola Folayan, "Trade Routes in Egbado in the 19th Century," in I.A. Akinjogbin and S.O. Osoba, eds., Topics on Nigerian Economic and Social History (Ife: University of Ife Press, 1980), $83-85$. 


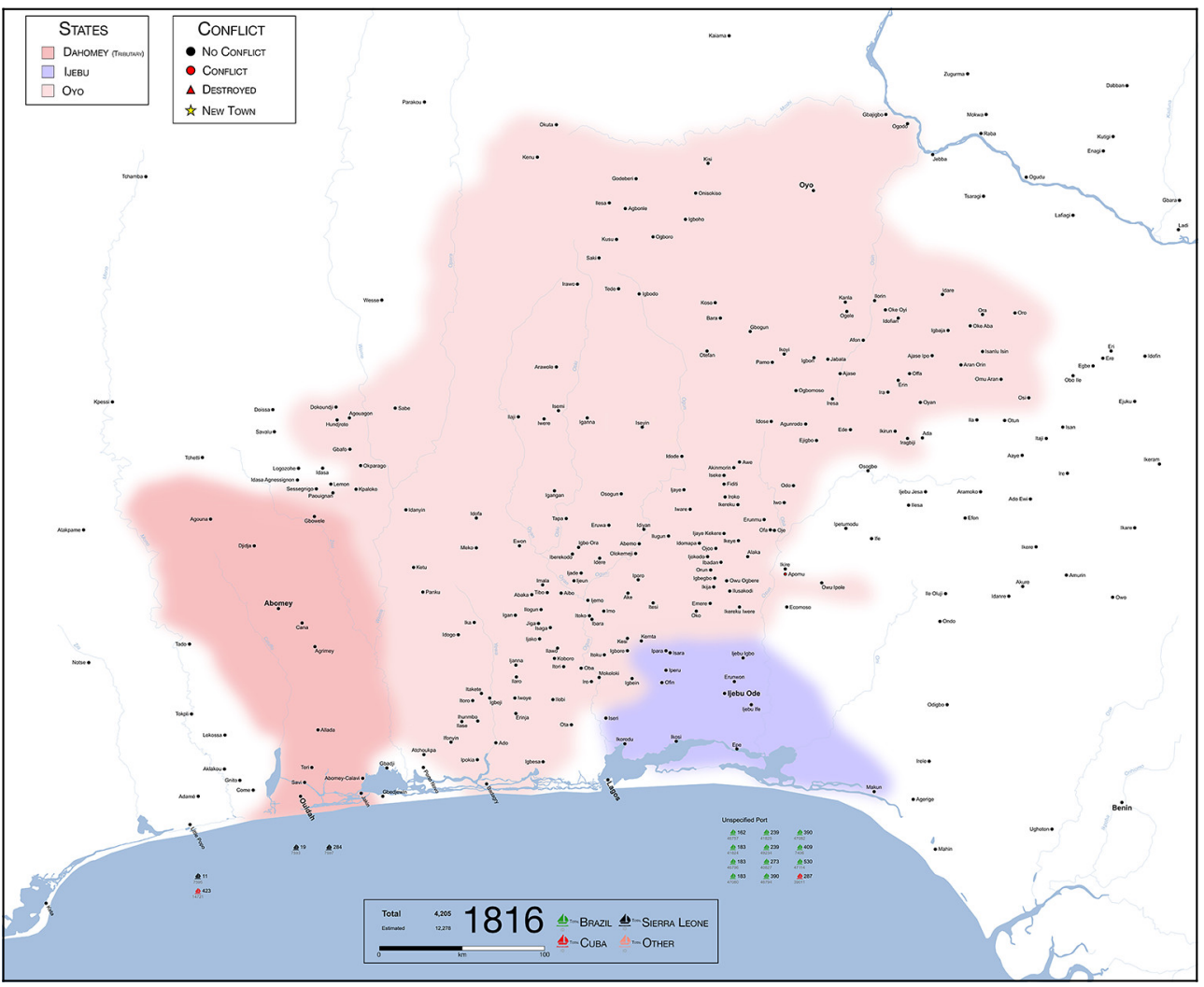

FIGURE $6 \quad$ Map of 1816

HENRY B. LOVEJOY, AFRICAN DIASPORA MAPS LTD., 2019

bances within the Oyo kingdom."28 On the map, the yellow polygon reflects the uprising spreading out from Ilorin. The geographical extent indicated therein is a matter of dispute. How to reflect the increasing number of undocumented revolts and disturbances in specific wards of provincial towns is highly uncertain. Nevertheless, Ilorin and surrounding towns asserted independence from Oyo.

Meanwhile, Ife, Ijebu and Ijesa formed a coalition against Oyo and Owu between 1817 and 1822. This war arose following the trade disputes at Apomu. The precise chronology for the Owu War is debatable. Some scholars argue that it began in 1820 and ended in 1827 . However, Law's periodization, which I have adopted, dates the conflict between 1817 and $1822 .{ }^{29}$ In order to represent the

28 Law, Oyo Empire, 255-257.

29 See Ajayi Kolawole Ajisafe, The History of Abeokuta (Abeokuta: Fola Bookshops, 1964), 49; 
duration of conflict, red dots are used for the two main Owu towns, Owu Ogbere and Owu Ipole, although there were many more towns not mentioned in the primary sources.

In 1817 , seven documented ships departed, six for Brazil from unspecified ports. Another went to Sierra Leone from Ouidah. Total documented and estimated departures, which differed only by two people, was just over 1,700 individuals during this year.

\subsection{Map of 1818 (https://doi.org/10.6084/m9.figshare.7976978)}

In this year, the Muslim uprising in Oyo and Owu War likely intensified. Without providing a specific date, Law explains how "Afonja's military operations seem to have been confined to the eastern provinces of the [Oyo] kingdom, but now his Fulani and Hausa allies extended their activities across the River Ogun into the western provinces." ${ }^{30}$ To reflect slave raiding activity west of the Ogun River, a red dot indicates the location of the town of Iseyin through 1821, which was the year of Samuel Crowther's enslavement. He described how "for some years, war had been carried on in my Eyo [Oyo]." In that year he was transported from his hometown of Osogun to Iseyin, which became "the rendezvous of the enemies." 31

Once Gezo succeeded to the throne in Dahomey, it is worth noting that the notorious, Brazilian-born slave trader, Francisco Felix de Souza, led a coup d'état from Little Popo to help with the Gezo's ascension. ${ }^{32}$ Thereafter, Dahomey fought annual campaigns, where at first the conquered "Gnito," which is likely the town of Grito to the west of Lake Ahémé to the north of Little Popo. ${ }^{33}$

In this year, there were twelve documented slave ships that went to Brazil, eleven of which left from unidentified ports, while one departed from Little Popo. Total documented departures were 2,868 individuals, while estimates were slightly more at 2,955 people.

Saburi Biobaku, ed., The Egba and Their Neighbours, 1842-1872 (Oxford: Clarendon Press, 1965), 13; Johnson. History of the Yorubas, 206-208; Law, Oyo Empire, 274-275; M.A. Mabogunje and J. Omer-Cooper, Owu in Yoruba History (Ibadan: Ibadan University Press, 1971). Law, Oyo Empire, 258.

31 Ajayi, "Crowther of Oyo," 299 and 303.

32 Robin Law, Ouidah: The Social History of a West African Slaving 'Port' 1727-1892 (Athens: Ohio University Press, 2004), 165; and Law, Oyo Empire, 271.

Mouléro, “Guézo," 52. 


\subsection{Map of 1819 (https://doi.org/10.6o84/m9.figshare.7976978)}

Much like the previous year, the Muslim uprising and Owu wars continued. This map expands the yellow border of Ilorin to reflect slave raiding near and along the Ogun River. At the coast, Law argues that "Lagos was entirely dependent upon the Ijebu port of Ikosi for its supply of slaves." ${ }^{4}$ Most enslaved people would have arrived to Lagos after being captured in the Owu Wars. Meanwhile, Gezo began to expand Dahomey's territorial limits by subjugating "Séréchi," which was likely the town of Tchetti to the northwest of Abomey. ${ }^{35}$

There were nineteen slave ships leaving the Bight of Benin all of which went to Brazil from unidentified ports, except for one ship departing from Keta, which likely did not have any people on board who had been involved in the major conflicts in the region under analysis. By this time, de Souza had returned to Ouidah. ${ }^{36}$ Total documented departures increased from the previous year at 4,764 individuals with estimates slightly higher at 5,010 people.

\subsection{Map of 1820 (https://doi.org/10.6o84/m9.figshare.7976978)}

The ongoing Muslim uprising and Owu War adversely affected the trade of Oyo. According to Law,

The lack of success of the Oyo armies meant that there was no longer any substantial supply of war captives for sale to the Europeans while the disturbances consequent upon the decline of Oyo power disrupted the major trade routes. In the south, Dahomian pressure had interfered with the supply of slaves to Porto Novo, driving the main center of slave trade eastwards to Lagos. The principal suppliers of slaves to Lagos were the Ijebu, and they were receiving their slaves not from Oyo, but from its dissident vassals, such as Ilorin, and from the $[\mathrm{Owu}]$ wars. ${ }^{37}$

Law adds that the Borgu towns in the north "sought to exploit Oyo's difficulties by raiding into the northwest of the Oyo kingdom."38 On the map, red dots reflect conflict at the Owu towns and Apomu, but also at Okuta, Kenu and Godeberi in the northwest. According to Mouléro, Gezo also fought a war in the Mahi town of Logozohe.

34 Law, Oyo Empire, 274.

35 Mouléro, "Guézo," 52. Law interprets variations of Mouléro's spelling of "Séréchi" in Robin Law, "Dahomey and the North-West," Cahiers du Centre de Recherches Africaines 8 (1994): 153.

36 Law, Ouidah, 165.

37 Law, Oyo Empire, 28o.

38 Ibid., 292. 
While Oyo's power declined at its periphery and its direct involvement in the slave trade decreased, fifteen slave ships departed from unidentified ports, all of which went to Brazil except one for Cuba. Meanwhile, de Souza's operations at Ouidah flourished. ${ }^{39}$ Total documented embarkations were 4,150 people with estimates slightly higher at 4,645 individuals.

\subsection{Map of 1821 (https://doi.org/10.6o84/m9.figshare.7976978)}

As the Owu wars neared their end and Borgu forces continued to raid Oyo's northwestern towns, jihād forces based at Iseyin destroyed Samuel Crowther's hometown of Osogun. ${ }^{40}$ Meanwhile, Gezo's armies unsuccessfully attacked the Mahi town of Hundjroto. ${ }^{41}$ In addition, Adele, the king of Lagos, went into exile at Badagry in $1821 .{ }^{42}$ Badagry earns a red dot because, according to Law, "Adele had to defend Badagry against attacks from Dahomey and Porto Novo."43

At this time, twelve ships departed from unspecified ports most of which went to Brazil, except for one ship leaving Lagos for Brazil and another from Badagry that was seized and taken to Sierra Leone. De Souza's position at Ouidah was further consolidated as the leading merchant "not from appointment by Gezo alone, but also from his claim to represent the Portuguese government" through permits to trade slaves directly to Brazil. ${ }^{44}$ Documented ship departures totaled 3,463 people, while 3,757 people are estimated to have left.

\subsection{Map of 1822 (https://doi.org/10.6o84/m9.figshare.7976978)}

This year marked the last year of the Owu war and the presumed destruction of Owu Ogbere and Owu Ipole. Meanwhile, the Borgu states continued raiding Oyo's northwestern territory, while Adele controlled trade at Badagry. However, Afonja, who had miscalculated "in seeking to make use of militant Islam for opportunist ends ... attempted to persuade the Fulani and Hausa to leave Ilorin and settle separately to the east." ${ }^{45}$ Consequently, the map depicts the territory of Ilorin receding to some degree as Muslim raids seem to have subsided. After

39 Law, Ouidah, 167.

40 Ajayi, "Crowther of Oyo," 299; and Law, Oyo Empire, 292.

41 Mouléro, "Guézo," 52.

42 Jamie Bruce Lockhart and Paul E. Lovejoy, "Introduction: An Expedition in the Interior of Africa under the Command of Captain Hugh Clapperton, R.N. (1825-1827)," in Bruce Lockhart and Lovejoy, eds., Hugh Clapperton Into the Interior of Africa, 43. Robin Law, "The Career of Adele at Lagos and Badagry, c. 1807-c. 1837," Journal of the Historical Society of Nigeria 9 (2) (1978): 35-59; and Law, Oyo Empire, 273.

44 Law, Ouidah, 168.

45 Law, Oyo Empire, $255^{-258 .}$ 
the defeat at Hundjroto, Gezo shifted his campaigns southwards laying siege to "Gbédjêwin," which is place name that relates to a neighborhood in Cotonou on the southern shores of Lake Nakoué. ${ }^{46}$

At the coast, the slave trade reached its highest levels since 1816 , whereby 26 slave ships departed. One left Porto Novo, eight left Ouidah, three left Porto Novo, one left Badagry, nine left Lagos and four departed from unspecified ports. Of these ships, seventeen went to Brazil, eight went to Sierra Leone and one French ship went to an unspecified place probably in the Caribbean. Total documented embarkations were 6,722 people, while estimates were 6,923.

\subsection{Map of 1823 (https://doi.org/10.6o84/m9.figshare.7976978)}

This year was pivotal for four reasons: 1) Ilorin became an emirate within the Sokoto Caliphate; 2) the defeat of Owu resulted in the systematic destruction of Egba towns; 3) Dahomey asserted its independence from Oyo; and 4) the Borgu towns of Nikki, Wawa, Parakou and Kaiama continued to raid the northwest. During these military offensives, slave trade departures decreased to the lowest numbers during the period of Oyo's collapse.

As attempts to expel Muslims from Ilorin failed, Afonja was executed. Thereafter, Ilorin "represented an alien power whose object was the complete destruction of the Oyo kingdom." ${ }^{47}$ The following quotes, which mostly derive from Johnson, summarize conflict around Ilorin:

Afonja had detached the Igbomina from allegiance to Oyo, and Ilorin forces had [destroyed] some important towns, such as Iresa, Igbon and Ejigbo. Also in possession of the Fulani, and in alliance with Ilorin, was the important commercial town of Raka [Ogodo], to the north-east of the capital. ${ }^{48}$

Raka [Ogodo] had been replaced by a new market town ... probably to be identified with Agbonle. It appears, moreover, that most of the slaves coming from the north were by-passing Oyo altogether, being taken through Borgu and Dahomey for sale at [Ouidah] ${ }^{49}$

Oyo organized a concerted attempt to crush the rising power of Ilorin ... A first attack was beaten back at the battle of Ogele, near Ilorin, and Ilorin

\footnotetext{
46 Mouléro, "Guézo," 53.

47 Law. Oyo Empire, 278.

48 Ibid., 279 .

49 Ibid., 282.
} 


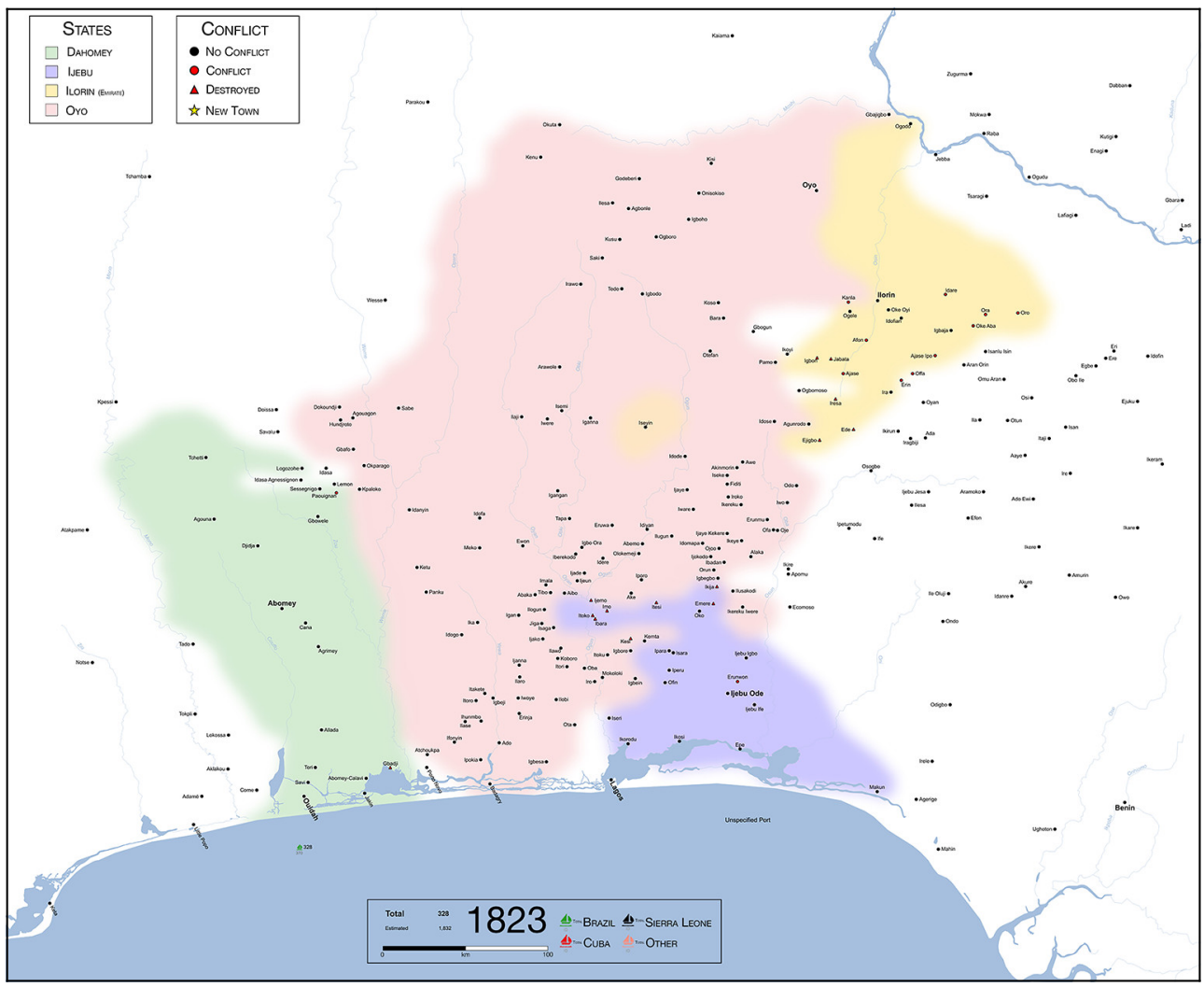

FIGURE 7 Map of 1823

HENRY B. LOVEJOY, AFRICAN DIASPORA MAPS LTD., 2019

forces followed up by raiding into the Ibolo province. In this extremity, the Oyo sought external assistance against Ilorin, and secured an alliance of the king of Nupe, Etsu Majiya II ... Nupe tradition records that his army included 4,0oo mounted troops. ${ }^{50}$

On the map, the Ilorin boundary shifts to a darker yellow to reflect its incorporation into the Sokoto Caliphate.

After the Owu wars, Ife and Ijebu forces formed an alliance with the Oyo refugees "to invade Egbaland, and one by one to destroy almost all the old Egba towns." ${ }^{11}$ Due to imprecise records, it has been nearly impossible to evaluate 
the progression of the destruction of these towns. In his interviews with the chief of Abeokuta, Ogubonna, in the 185os, Irving learned that

From this town of Owu, the conquerors passed to Ikija ... which was accused of having assisted Owu with provisions. From thence the conquering army of Ifes, Ijebus, Yorubas, proceeded against other towns of the Egbas. Kesin and Emere soon fell. They then settled in the Egba towns of Erunwon and Ijemo, and a part pitched on the road to Itoko. Here they found cause of quarrel with Ijemo, and destroyed it. Itoko next fell. Returning through the ruins of Ijemo they passed through Oba and Itoku to Ijeun. ${ }^{52}$

Saburi Biobaku, as well as M.A. Mabogunje and J. Omer-Cooper, confirm this context and chronology. ${ }^{53}$ Since Ijebu was the primary aggressor, I have indicated the progression of the destruction of Egba towns with a blue boundary. After a town was attacked or destroyed, the blue border recedes and the base map remains white to illustrate the dissolution of town after town which is represented as occurring on an annual basis in the absence of more precise data.

To reflect the change in Dahomey's independence from Oyo on the map, the kingdom's boundaries shift from a dark pink to green. According to Law, "Gezo met and repulsed Oyo at Paouignan, in the Mahi country" ${ }^{44}$ At the coast, Dahomey also attacked "Gbadji." 55 On modern maps, however, Ouédo-Gbadji is the elevated town built on stilts in Lake Nakoué. Following the campaign at Gbedjewin the year before, it is more likely, in my opinion, that Dahomey destroyed Gbadji to secure all of Lake Nakoué and further infringe upon Oyo's interests around Porto Novo.

Amazingly, there was only one documented ship leaving Ouidah for Brazil with 328 people on board, which suggests the various military actions resulted in less people being transported to the coast at this time.

\footnotetext{
52 Irving, "Ijebu Country," 67.

53 Biobaku, Egba, 13; and Mabogunje and Omer-Cooper, Owu, 57.

54 Law, Oyo, 271.

55 Mouléro, "Guézo," 53. I argue against Law, who states that Gbadji referred to "a Dahomian attack on a place on the coast which was tributary to Oyo, probably Badagry." See Robin Law, "The Oyo-Dahomey Wars, 1726-1823: A Military Analysis," in Toyin Falola and Robin Law, eds., Warfare and Diplomacy in Precolonial Nigeria (Madison: African Studies Program, University of Wisconsin-Madison, 1992), 17.
} 


\subsection{Map of 1824 (https://doi.org/10.6o84/m9.figshare.7976978)}

With Oyo under siege on all fronts, two new towns were established, namely Akesan and Ago Oja (the eventual site of "New Oyo"). Also, the ruler of Ede "moved his town southwards across the River Osun as a precaution against Fulani raids and set about attacking and reducing neighbouring towns in the Ibolo province." ${ }^{\text {6 }}$ Law explains that "after the removal of Afonja, many of the eastern towns, such as Ikoyi, Ogbomoso, Gbogun, and Ede, were to rally to the Alafin [of Oyo]." 57

As Irving described without much specification in the 1850 os, "divisions of the [Ijebu] army went out daily, kidnapping and destroying the smaller Egba towns, the Ijebu slave-traders always offering a ready market for their captives." ${ }^{18}$ In the 18gos, Johnson explained how the coalition, which included many Oyo refugees, made several expeditions "from their base at Ipara, whereby Iporo, Oba, Itoko, Itesi, Imo, Ikereku, Itoku, etc., were taken." ${ }^{\prime 59}$ As the offensive continued, "Itoko shared its fate and [then Ijebu and their allies] occupied Oba, Itoku, and Ijeun." ${ }^{00}$ In apparent attempts to recover, Egba refugees from "Igbore, Imo and Igbein [Egba refugees] allied to march against [Ijebu forces at] Ipara." ${ }^{\prime 61}$ Unfortunately, the available primary sources do not convey a chronological sequence of events; thus, it becomes necessary to confront this uncertainty and make decisions to reflect the systematic destruction of Egba towns before 1830 .

Elsewhere, Dahomey fought a campaign against "Sessenigo," which is identified by novelist Paul Hazoumé as being in "Mahi country." ${ }^{2}$ The siege of Paouignan occurred at the same time which suggests that Sessenigo was likely nearby, and on the map, I have estimated its probable location.

At the coast, nine documented slave ships departed, three of which went to Cuba, three to Sierra Leone, two to Brazil and one to an unspecified place. These vessels left from Ouidah, Badagry and Lagos with documented departures being 3,411 people, although more than 6,500 are estimated to have left, which was a substantial increase from the previous year.

\footnotetext{
$56 \quad$ Ibid., 28o.

57 Law, Oyo Empire, 281.

58 Irving, "Ijebu Country," 71.

59 Johnson, History of the Yorubas, 223-224.

6o Biobaku, Egba, 13; and Mabogunje and Omer-Cooper, Owu, 62.

61 Law, Oyo Empire, 281.

62 Mouléro, “Guézo," 53; Hazoumé, Doguicimi, 405; and email with Robin Law, 23 June 2018.
} 


\subsection{Map of 1825 (https://doi.org/10.6o84/m9.figshare.7976978)}

In 1825 , Ilorin defeated the Nupe and Oyo alliance that had been formed in 1823, whereby the Nupe capital at Raba on the Niger River fell to jihäd forces. According to Law, "Ilorin meanwhile followed up their victory in the Mugbamugba War by taking the important town of Ofa, in the Ibolo province."63

This year also marked the beginning of Clapperton and Lander's journey from Badagry to Sokoto. Due to the various pockets of regional conflict, the expedition was taken through a narrow corridor winding around granite hills of a high plateau from Badagry through Ipokia, Ihumbo, Ilaro, Ijanna, Aibo, Saki and onto the Oyo capital. Without fully understanding local events and the geography, Clapperton's reports of heavily defended villages essentially reflected the breakdown of Oyo's effective power in the region. Jamie Bruce Lockhart and Paul Lovejoy demonstrate how Clapperton's visit occurred “when Oyo retained only the merest toe-hold in Egbado." 64

According to oral traditions collected by the missionary H. Townsend, Egba refugees first settled at Abeokuta. ${ }^{65}$ The actual date of the foundation of Abeokuta is unclear, but it grew rapidly after 1825. In Mahi territory to the northeast of Dahomey, "Oyo forces fled in retreat across the River Weme" leaving their tributary Mahi towns to defend themselves thereafter. ${ }^{66}$ Dahomey continued to wage war in the region destroying the town of Lemon. ${ }^{67}$

On the coast, nineteen slave ships departed from the coast between Little Popo and Lagos. They mostly went to Sierra Leone (8), Brazil (5), Cuba (4) and elsewhere (2). Total documented departures were 6,303, but estimates of departures from unknown locations soared to 12,425 people.

\section{$2.11 \quad$ Map of 1826 (https://doi.org/10.6o84/m9.figshare.7976978)}

As Ilorin continued to raid Oyo territory, especially around Ikoyi and Pamo, violence escalated further in Egbaland. Ijebu "attacked Ikereku [which was] a useful market for [supplying] food stuffs." ${ }^{\prime \prime}$ Itoku, Oba and Eruwon allied with Ikereku. According to Mabogunje and Omer-Cooper, "the siege lasted several months .... The fall of Ikereku can be accurately dated to 1826. After the

\footnotetext{
63 Law, Oyo Empire, 285.

64 Bruce Lockhart and Lovejoy, "Introduction," 43-44; and Folayan, "Trade Routes in Egbado," 83-95.

65 Church Missionary Society, CA2/085, Journal of H. Townsend, 23 December 1847.

66 Law, Oyo Empire, 271 and 283.

67 Mouléro, "Guézo," 53.

68 Mabogunje and Omer-Cooper, $\mathrm{Owu}, 62$.
} 
destruction of Ikereku, [the Egba army] moved to the northern part of the Egba country." ${ }^{\prime 9}$ Bioabku confirms this date. ${ }^{70}$

After Oyo's retreat from Mahi territory, Law has demonstrated that Dahomey traders began buying slaves at Wawa, to the northeast of Kaiama in Borgu and on the Niger River at Yauri. ${ }^{71}$ Dahomey attacked "Adjassè," which seems to refer to Ajase, which is the Yoruba name for Porto Novo. ${ }^{72}$ However, Hazoumé states that this place was "another Mahi region." ${ }^{73}$ After consulting with Law and Ojo, I elected to interpret "Adjassè" as Porto Novo to illustrate Dahomey's ongoing policy of blocking Oyo trade at the coast.

Fifteen voyages departed including those for Sierra Leone (6), Brazil (5), Cuba (2) and elsewhere (1). Shipping activity mostly concentrated at Ouidah, although ships left Badagry, Lagos and Little Popo, as well as unspecified locations. Total documented departures were 5,512 people, while estimates from unspecified locations were just over 8,800 .

\subsection{Map of 1827 (https://doi.org/10.6084/m9.figshare.7976978)}

The primary and secondary sources do not refer to the activities of Ilorin capturing specific places, although slave raiding must have been occurring regularly. In Egbaland, the Ijebu army engaged "in a conflict between the Egba Gbagura town of Orun and neighbouring Idomapa."74 However, many Egba towns realized that no help was coming from Oyo and no longer fell under Oyo control. Otherwise, Dahomey continued to undermine Oyo through its constant slave raiding in Mahi territory, including the destruction of Doissa. ${ }^{75}$

In this year, there may have been a lull in inland raiding as slave trading activities declined slightly at the coast. Only eleven slave ships departed, including seven for Brazil and four that were taken to Sierra Leone. Documented totals reached just over 4,00o, while estimates were not much higher.

\subsection{Map of 1828 (https://doi.org/10.6o84/m9.figshare.7976978)}

Ilorin continued to attack Oyo, while the Egba attempted to unite in the face of Ijebu inroads. According to Mabogunje and Omer-Cooper, "many towns were deserted and most of them set on fire by their own inhabitants. Following up

\footnotetext{
$69 \quad$ Ibid., 62.

70 Biobaku, Egba, 14.

71 Law, "Slave-Traders and Middlemen," 58.

72 Mouléro, "Guézo," 53.

73 Hazoumé, Doguicimi, 405.

74 Mabogunje and Omer-Cooper, Owu, 62.

75 Mouléro, “Guézo," 53.
} 
their victory, [the Ijebu army] pushed through Ijayie-Maja, Kosi-Kosi, Ikerekuiwere, Ora, Ibadan, Ojokodo, Iwohaha and Eguoto the same night and reached Ojoho."76 Dahomey, meanwhile, fought a second, successful campaign against the Mahi town of Hundjroto. ${ }^{77}$

At the coast, the slave trade was in relative decline with only ten documented voyages, including six taken to Sierra Leone, three that went to Cuba and one to Brazil. Documented totals dipped to 3,458 individuals, while just over 5,000 people are estimated to have left unspecified points.

\subsection{Map of 1829 (https://doi.org/10.6o84/m9.figshare.7976978)}

Ilorin slave raiding was widespread throughout the Oyo savanna. This year marks the foundation of Ibadan as a refugee center in the south. Initially, Ife armies dominated the new town, but as Oyo and Owu refugees arrived, they became strong enough to expel the Ife chiefs. According to Biobaku, many Egba factions attempted to settle at Ibadan only to find they were not welcome and many people were even enslaved. As a result, groups of Egba fled the town and "encamped on the other side of the Ona River." ${ }^{\text {" T }}$ Thereafter, Ibadan became a predominately Oyo town concentrated on counterattacking Ilorin. Ibadan did not oppose Ife and Ijebu raiding into Egba territory and even traded with rivals in exchange for European merchandise from the coast. ${ }^{79}$

Dahomey incursions in Mahi territory continued, including the destruction of Dokoundji, while the kingdom of Ketu likely distanced itself from Oyo at this time. ${ }^{80}$

At the coast, the slave trade rebounded, although British suppression also increased. Eleven ships were intercepted and taken to Sierra Leone, while three ships went to Brazil and one to Cuba, of which ten of these ships left from Lagos

76 Mabogunje and Omer-Cooper, $\mathrm{Owu}, 62$.

77 Mouléro, "Guézo," 53. Sylvain C. Anignikin claims that the destruction of Hundjroto occurred in 1832, which is doubtful. See "Histoire des populations mahi: À propos de la controverse sur l' ethnonyme et le toponyme 'Mahi,'” Cahiers d'Études Africaines 41, no. 162 (2001): 249 .

78 Biobaku, Egba, 14.

79 Toyin Falola, The Political Economy of a Pre-Colonial African State: Ibadan, 1830-1900 (IleIfe: The University of Ife Press, 1984), ch. 1; Toyin Falola, "Warfare and Trade Relations Between Ibadan and the Ijebu in the Nineteenth Century," in Toyin Falola and Robin Law, eds., Warfare and Diplomacy in Precolonial Nigeria (Madison: African Studies Program University of Wisconsin-Madison, 1992), 26; Johnson, History of the Yorubas, 206-208; Law, Oyo Empire, $275^{-276 .}$

8o See Mouléro, “Guézo," 53; and E.G. Parrinder, The Story of Ketu:An Ancient Yoruba Kingdom (Ibadan: Ibadan University Press, [1956] 1967). 


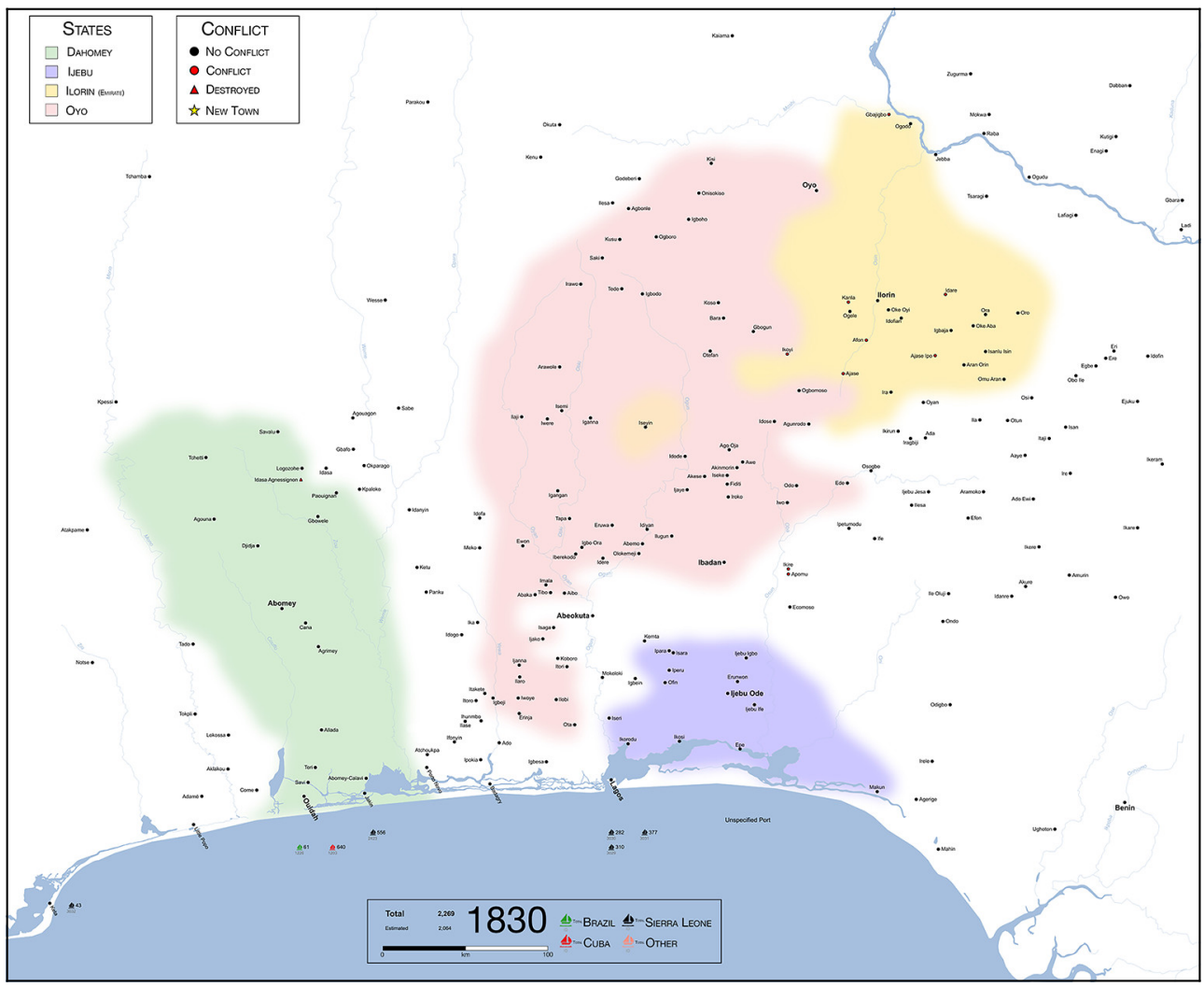

FIGURE 8 Map of 1830

HENRY B. LOVEJOY, AFRICAN DIASPORA MAPS LTD., 2019

(10). Total documented departures were over 5 ,ooo people while an estimated 6,3 oo individuals left from unspecified points.

\subsection{Map of 1830 (https://doi.org/10.6o84/m9.figshare.7976978)}

The constant slave raiding on all fronts weakened Oyo's capacity to respond to Ilorin. Despite increased supplies of guns and ammunition, Oyo and Ilorin reached a "formal accommodation," whereby the Alafin Majotu of Oyo acknowledged Ilorin's independence and permitted "trade on the condition that no more Fulani were admitted to the town." ${ }^{81}$ Troops from Gwandu captured the trading town of Gabjigbo, close to the Niger River, which weakened Oyo further. A drought added to the stress of conflict at this time. ${ }^{82}$

81 Law, Oyo Empire, 287-288.

82 Ibid., $287-288$. 
The rapid growth of both Ibadan and Abeokuta reflected a period of intense urbanization. Folayan has argued that "Abeokuta compressed the Egba who had formerly occupied 300 towns and villages to about one-third of their former territory .... Egba's need for more land, caused by their being crammed into a small space, was to be satisfied in Egbado, a process which necessitated Egba invasions into, and gradual domination of, parts of Egabdo." ${ }^{83}$ The primary sources do not contain the names of "30o Egba towns and villages;" thus these missing data cannot be plotted on the maps. As Abeokuta grew in size, however, "Ijebu armies attacked the farms around Abeokuta." 84

In Mahi territory, Dahomey's campaign against "Dossa-Agnessignon" likely relates to a place near the Yoruba-speaking enclave of Idasa and perhaps the unidentifiable Mahi town of "Sessegnigo;" and hence the location that I have assigned to this place is debatable. ${ }^{85}$

At the coast, only seven slave ships departed, including five taken to Sierra Leone, one that went to Brazil and another to Cuba. Total documented and estimated departures decreased to just over 2,ooo people, as it appears that British suppression was having a significant impact. ${ }^{86}$

\subsection{Map of 1831 (https://doi.org/10.6o84/m9.figshare.7976978)}

This year marks the end of Majotu's reign as Alafin and the brief reign of Amodu that lasted until 1832. Several key Oyo towns were abandoned in part due to drought and Fulani incursions that apparently undermined farming. Law describes how forces from Ogodo and Ilorin "entered and plundered Oyo," which now became a tributary to Ilorin. The "shock of the Ilorin conquest of the capital, produced a 'ramshackle coalition' among the rulers of Ikoyi, Gbogun, Ago Oja and Kanla, whereby Kanla and Ikoyi became tributaries to Ilorin."87 Around Abeokuta, the predominately Egba and Owu refugees "repulsed Ibadan and Ijebu far into Ijebu country near Isheri." 88 Dahomey attacked "Okparago," which is likely to be identified with the modern town of Okpara. ${ }^{89}$

Only five voyages departed the coast, two for Cuba, one for Brazil, one for Sierra Leone and another to unknown destination. Documented totals were

\footnotetext{
83 Kola Folayan, "Egbado to 1832: The Birth of a Dilemma," Journal of the Historical Society of Nigeria 4 (1) (1967): 30.

84 Biobaku, Egba, 16-18.

85 Mouléro, "Guézo," 53.

86 In this case, estimated departures $(2,064)$ totaled less than documented departures $(2,269)$.

87 Law, Oyo Empire, 289.

88 Biobaku, Egba, 18.

89 Mouléro, “Guézo," 53.
} 
less than 2,00o people, while estimates for those leaving unspecified points suggest over 3,000 people.

\subsection{Map of $183^{2}$ (https://doi.org/10.6o84/m9.figshare.7976978)}

Pro-Oyo forces attempted to regroup at Akese, but Ilorin pursued and destroyed Gbogun. Ago Oja allied with Ilorin, while Saki and Iganna became tributaries to Ilorin. Overall, Ilorin overran most of Oyo's Ibarapa province, destroying several undocumented towns and raiding "as far south as Abeokuta." ${ }^{90}$ According to Law, "the only check to Ilorin expansion ... came when an Ilorin army attempted an invasion of Ijesa country ... [but] they found that the forests of Ijesaland were unsuited for the operation of their cavalry." ${ }^{11}$ In the south, the Owiwi war involved an attempt by Ijebu, "assisted by a small Ibadan contingent," to attack Abeokuta, but the offensive was repulsed at Owiwi Creek. Dahomey attacked the town of Kpaloko. ${ }^{92}$

At the coast, there were only five documented slave ships, three destined for Cuba and one each to Brazil and Sierra Leone. Documented totals were around 2,5 oo people, while over 7,00o individuals left from unspecified places.

\subsection{Map of 1833 (https://doi.org/10.6o84/m9.figshare.7976978)}

This year marks the end of the reign of Alafin Amodu, who was succeeded by Oluewu, the last Alafin of Oyo. By this time Ilorin "had either destroyed or subjected almost all of the important Oyo towns," including Ofa, Ikoyi, Gbogun, Saki, Iganna, Akese, Ago Oja and Ogbomoso. Law explains how only Ede "was shielded from direct attack by the River Osun, [while] the only independent Oyo powers were the newly established states in the south: Ijaye, Abemo, and Ibadan. ${ }^{93}$ At Badagry, Adele still held control over most of the Yewa river corridor. Following the Owiwi war, Abeokuta and Adele's Badagry mounted a counterattack against Ijebu and a contingent from Ibadan. According to Folayan, this conflict

Resulted in the "mediatization" of the important Egbado kingdoms of Ilaro and Ijanna, and the reduction of Ilobi, Igebji and several other towns and villages in central Egbado, thereby establishing Egba power in the

\footnotetext{
$90 \quad$ Law, Oyo Empire, 290.

91 Ibid., 291.

92 Mouléro, “Guézo," 53. Earlier, Law suggested that the campaign against Kpaloko occurred in the early-to-mid 1820s, but later changed his opinion. See Law, Oyo Empire, 271-272; and Law, "The Oyo-Dahomey Wars," 17-20.

93 Law, Oyo Empire, 291.
} 
area. Henceforth, just as Dahomey constituted a threat to Egbado political security from the west, so did the Egba state become another pressure. ${ }^{94}$

Johnson reports that the former rulers of Ilaro and Ijanna branched off and the town "Refurefu was founded by c. 1833," along with Oke Odan. ${ }^{95}$ According to Law, Adele

assisted the Egba in these campaigns also, first by sending firearms and gunpowder to them up the River Ogun, and later by himself leading an army to their support; his personal intervention in the fighting probably occurred not at the battle of the Owiwi itself, but during the subsequent Egbado campaign, in which his forces are said to have taken the towns of Ilobi and Igbeji. ${ }^{96}$

Meanwhile, Dahomey attacked the town of Atchoukpa to the north of Porto Novo. ${ }^{97}$

At the coast, five slave ships departed, four heading to Cuba and one to Brazil. Documented totals were 2,163 people, although estimates suggest the departure of over 6,ooo individuals.

\subsection{Map of 1834 (https://doi.org/10.6o84/m9.figshare.7976978)}

In ongoing attempts to reassert Oyo independence, Alafin Oluewu found support in factions of Bariba from Borgu, who had also "suffered invasions by forces from Gwandu." The Bariba allies included contingents from Kaiama, Nikki, Wawa and Bussa; and together they "crushed the opposition" at the capital city of Oyo. In the aftermath, the Oyo and Bariba alliance recaptured the towns of Saki, Igbodo, Iganna, Iseyin and Otefan. ${ }^{98}$ Abeokuta attacked Ijebu encamped at Mokoloki, Igbein and Kemta, while Dahomey attacked a place called "Adodiza," which might refer to Ado on the Yewa River. ${ }^{99}$

In this year, ten slave ships departed, five for Cuba, one each for Brazil and the United States; and three were taken to Sierra Leone. Documented departures totaled 4,144 people, while the estimates for unspecified locations surged to over 13,00o people.

\footnotetext{
94 Folayan, "Egbado to 1832," 31.

95 Johnson, History of the Yorubas, 270; Law, Oyo, 277.

96 Law, "Career of Adele," 53.

97 Mouléro, “Guézo," 53.

98 Law, Oyo Empire, 293-294.

99 Mouléro, "Guézo," 53.
} 


\subsection{Map of 1835 (https://doi.org/10.6o84/m9.figshare.7976978)}

Oyo's final attempt to regain control of former territory occurred following the rainy season, when Oyo and Bariba forces, with reinforcements from Ede, Ijaye, Abemo and Ibadan, recaptured Ogbomoso. ${ }^{100}$ Dahomey laid siege to "Fangni," which is likely the town of Ifonyin. At the coast, six vessels departed, three for Cuba, one for Brazil and two taken to Sierra Leone.

Documented totals report 2,418 people, while estimates for those leaving unspecified ports accounted for over 7,500, which was less than the previous year but still substantial.

\subsection{Map of 1836 (https://doi.org/10.6o84/m9.figshare.7976978)}

In this year marks the capital district of Oyo was finally abandoned with the flow of refugees southward from the former metropolitan district. For this reason, the year also marks the end of the mapping series. In the political void following the collapse of Oyo, several new states began to jockey for territorial control, including Abeokuta, Ilorin, Ibadan, New Oyo, Ijaye, Ijebu, Ife, among others. ${ }^{101}$ Dahomey continued its campaigns into Egbado and Awori territory, destroying the new town of Refurefu. ${ }^{102}$

At the coast, six vessels departed, three for Cuba, one for Brazil and two that went to Sierra Leone. Documented totals increased to 4,176 people, while estimates for unspecified points were over 9,ooo people.

Historical GIS scholars are increasingly interested in the problems associated with uncertainty, which constitutes a growing field of geographic and historical research. ${ }^{103}$ This digital humanities experiment explores how to extract georeferenced historical data from the scholarship of pre-colonial, sub-Saharan West Africa, along with slave trading data, for the development of spreadsheets designed to work with QGIS. By identifying places of conflict, the probable origins of when and where people came from in the interior before boarding slave ships at the coast can be postulated. The preliminary outcomes raise questions as to the validity of the representations that these annual maps try to portray, especially in consideration of imprecise data derived from historical sources

\footnotetext{
100 Law, Oyo Empire, 294.

101 Ibid., 303-312.

102 Mouléro, "Guézo," 53.

103 Knowles and Hillier, Placing History, 19.
} 


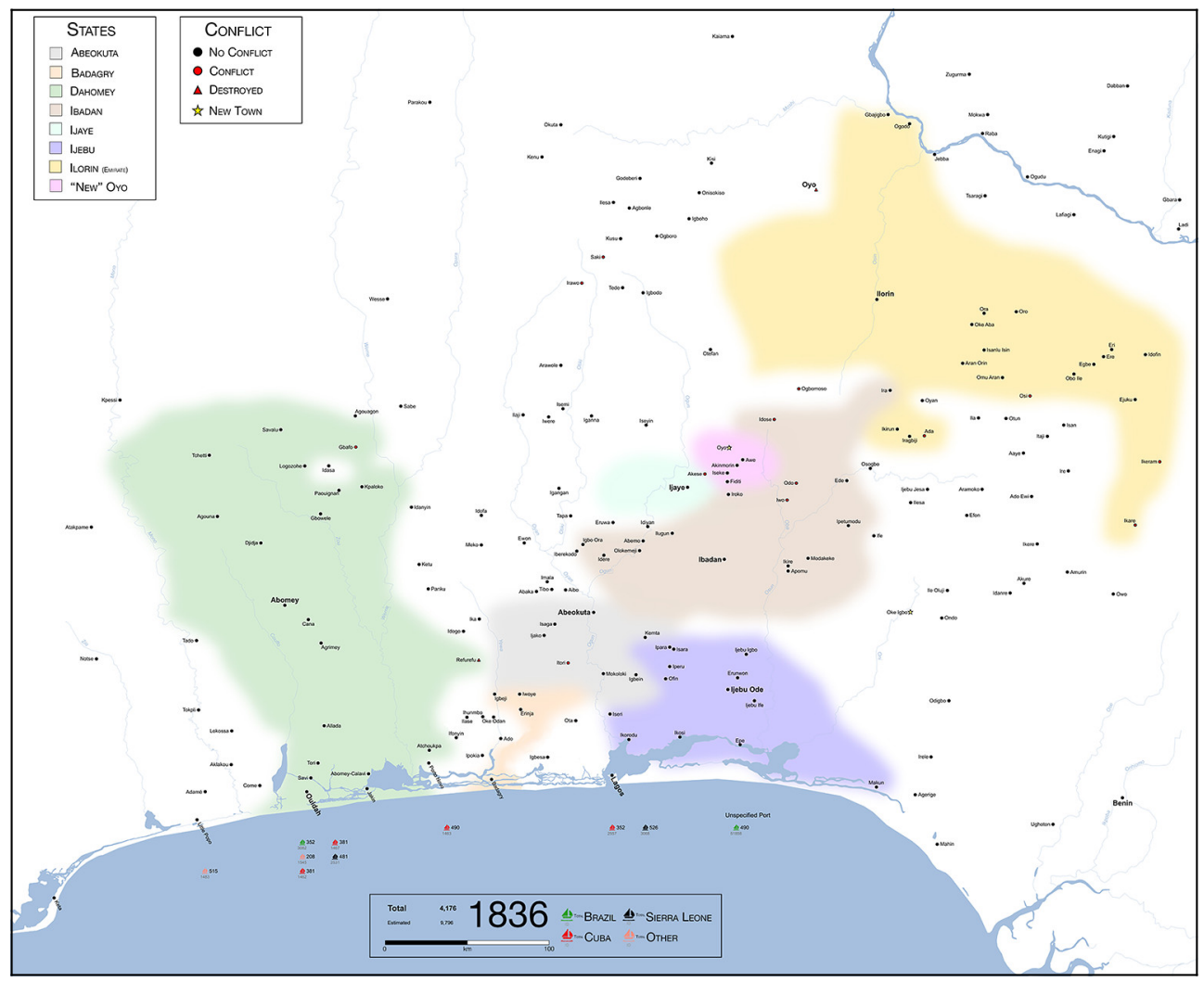

FIGURE 9 Map of 1836

HENRY B. LOVEJOY, AFRICAN DIASPORA MAPS LTD., 2019

which are more often than not vague unto themselves. Moreover, the issue of missing data compounds the problem of legitimacy further. Other methodological issues emerge due to the limitations and functionality of GIS software. Arbitrary dating remains a major issue, especially since slave voyage data works well with a Roman calendar, which does not easily conform to how conflict within Africa generally transpired. In the Bight of Benin hinterland, most campaigns occurred during the dry season between December and March/April.

The intention here is not to suggest that these maps are authoritative or accurate, but rather their presentation indicates potential methods in Historical GIs that might further the study of African and African diaspora history. A scalable model could be used to explore other regions within Africa, whereby a logical step would be to map the consolidation of the Sokoto Caliphate after 1804 and its expansion until the 185 os. Geo-referenced historical data have the potential to establish probabilities of African origins using applied mathemat- 
ics involving Gaussian distributions, Markov chains and kriging in the Laboratory of Interdisciplinary Statistical Analysis at the University of Colorado Boulder. ${ }^{104}$ Furthermore, these data may interest economic historians who also explore intra-African conflicts and the suppression of the slave trade in relation to land, labor and capital. ${ }^{105}$ The registers of those identified as Liberated Africans and the interpretation of documented African names may in time corroborate statistical models of probabilities and economic theory to unravel the ethnolinguistic configuration of trans-Atlantic migrations; thus, more clearly help to determine African origins and/or internal population estimates. ${ }^{106}$

\section{Acknowledgments}

I would like to acknowledge Marcel Fortin, Anne Kelly Knowles, Robin Law, Byron Moldofsky, and Olatunji Ojo for helping with data development and QG IS troubleshooting.

\section{Works Cited}

Ajayi, J.F. Ade. (1967). "Samuel Ajayi Crowther of Oyo." In: P. Curtin, ed., Africa Remembered: Narratives by West Africansfrom the Era of the Slave Trade. Madison: University of Wisconsin Press, pp. 289-316.

Ajisafe, Ajayi Kolawole. (1964). The History of Abeokuta. Abeokuta: Fola Bookshops.

Anignikin, Sylvain C. (2001). "Histoire des populations mahi: À propos de la controverse sur l'ethnonyme et le toponyme 'Mahi,'” Cahiers d'Études Africaines 41 (162), pp. $243^{-265}$.

Apter, Andrew. (2013). "Yoruba Ethnogenesis from Within." Comparative Studies in Society and History 55 (2), pp. 356-387.

104 Studies are being conducted in the Laboratory of Interdisciplinary Statistical Analysis at the University of Colorado Boulder under the direction of Henry Lovejoy and Eric Vance.

105 James Fenske and Namrata Kala, "1807. Economic Shocks, Conflict and the Slave Trade," Journal of Development Economics 126 (2017): 66-76; James Fenske, "Land Abundance and Economic Institutions: Egba Land and Slavery, 1830-1914," Economic History Review 65 (2) (2012): 527-555; Nathan Nunn, "The Long-Term Effects of Africa's Slave Trades," The Quarterly Journal of Economics (Feb. 2008): 139-176; Sandra Sequeira, Nathan Nunn, and Nancy Qian, "Migrants and the Making of America: The Short- and Long-Run Effects of Immigration during the Age of Mass Migration," CEPR Discussion Papers (2017): 1-49.

106 David Eltis, and Philip Misevich, dirs. African Origins. http://african-origins.org. (Accessed in 2018); and Lovejoy, Liberated Africans. 
Biobaku, Saburi, ed. (1965). The Egba and Their Neighbours, 1842-1872. Oxford: Clarendon Press.

Bodenhamer, David J., Corrigan, John, and Harris, Trevor M., eds. (2010). The Spatial Humanities: GIS and the Future of Humanities Scholarship. Bloomington: Indiana University Press.

Boonstra, Onno. (2010). "Barriers Between Historical GIS and Historical Scholarship." International Journal of Humanities and Arts Computing 3 (1), pp. 3-7.

Bruce Lockhart, Jamie, and Lovejoy, Paul E., eds. ([1829] 2005). Hugh Clapperton Into the Interior of Africa: Records of the Second Expedition, 1825-1827. Leiden: Koninklijke Brill N.v.

Curtin, Philip. (1967). "Joseph Wright of the Egba." In: Philip Curtin, ed., Africa Remembered: Narratives by West Africans from the Era of the Slave Trade. Madison: University of Wisconsin Press, pp. 318-320.

DIVA-GIS. (Accessed 2014). http://www.diva-gis.org/gdata.

Doorn, Peter. (Accessed 2019). "A Spatial Turn in History." gIM International. https:// www.gim-international.com/content/article/a-spatial-turn-in-history.

Eltis, David. dir. (Accessed 2019). Voyages: The Trans-Atlantic Slave Trade Database. http://slavevoyages.org.

Eltis, David, and Misevich, Philip, dirs. (accessed in 2019). African Origins. http://african -origins.org.

Fage, J.D. (1958). An Atlas of African History. London: Edward Arnold Ltd.

Falola, Toyin. (1984). The Political Economy of a Pre-Colonial African State: Ibadan, 183019oo. Ile-Ife: The University of Ife Press.

Falola, Toyin. (1992). "Warfare and Trade Relations Between Ibadan and the Ijebu in the Nineteenth Century." In: Toyin Falola and Robin Law, eds. Warfare and Diplomacy in Precolonial Nigeria. Madison: African Studies Program University of WisconsinMadison, pp. 26-30.

Fenske, James. (2012). "Land Abundance and Economic Institutions: Egba Land and Slavery, 1830-1914." Economic History Review 65 (2), pp. 527-555.

Fenske, James, and Kala, Namrata. (2017). "1807: Economic Shocks, Conflict and the Slave Trade." Journal of Development Economics 126, pp. 66-76.

Folayan, Kola. (1967). "Egbado to 1832: The Birth of a Dilemma." Journal of the Historical Society of Nigeria 4 (1), pp. 83-95.

Folayan, Kola. (1980). "Trade Routes in Egbado in the 19th Century." In: I.A. Akinjogbin and S.O. Osoba, eds., Topics on Nigerian Economic and Social History. Ife: University of Ife Press, pp. 81-83, 100-102.

Gaffield, Chad. (Accessed 2019). "Map Quests: Scaling the Past in the Digital Age." Perspectives on History. https://www.historians.org/publications-and-directories/ perspectives-on-history/october-2016/map-quests-scaling-the-past-in-the-digital -age. 
Gregory, Ian N., and Ell, Paul S. (2007). Historical GIs: Technologies, Methodologies and Scholarship. Cambridge: Cambridge University Press.

Hazoumé, Paul. ([1938] 1978). Doguicimi. Paris: Maisonneuve et Larose.

Irving, Edward. (1856). “Ijebu Country." Church Missionary Intelligencer 7, pp. 65-72, 9398 and $118-120$.

Johnson, Samuel. (1921). The History of the Yorùbás from the Earliest Times to the Beginning of the British Protectorate. London: Routledge \& Sons Limited.

Knowles, Anne Kelly. (2005). "Emerging Trends in Historical GIs." Historical Geography 33, pp. 7-13.

Knowles, Anne Kelly. (2014). "Why We Must Make Maps: Historical Geography as a Visual Craft." Historical Geography 42, pp. 3-26.

Knowles, Anne Kelly. (2016). "Historical Geographic Information Systems and Social Science History." Social Science History 40 (4), pp. 741-750.

Knowles, Anne Kelly, and Hillier, Amy, eds. (2008). Placing History: How Maps, Spatial Data and GIS Are Changing Historical Scholarship. Redland: ESR I Press.

Lander, Richard. (1830). Records of Captain Clapperton's Last Expedition to Africa. 2 vols. London: Colburn and Bentley.

Lander, Richard, and Lander, John. (1832). Journal of an Expedition to Explore the Course and Termination of the Niger. 2 vols. London: John Murray.

Law, Robin. ([1977] 1991). The Oyo Empire, c. 1600-c. 1836: A West African Imperialism in the Era of the Atlantic Slave Trade. Brookfield: Gregg Revivals.

Law, Robin. (1978). "The Career of Adele at Lagos and Badagry, c. 1807-c. 1837." Journal of the Historical Society of Nigeria 9 (2), pp. 35-59.

Law, Robin. (1992). “The Oyo-Dahomey Wars, 1726-1823: A Military Analysis.” In: Toyin Falola and Robin Law, eds., Warfare and Diplomacy in Precolonial Nigeria. Madison: African Studies Program University of Wisconsin-Madison, pp. 9-25.

Law, Robin. (1994). "Dahomey and the North-West." Cahiers du Centre de Recherches Africaines 8, pp. 149-167.

Law, Robin. (2004). Ouidah: The Social History of a West African Slaving 'Port' 1727-1892. Athens: Ohio University Press, 2004.

Le Herissé, A. (1911). L'ancien royaume de Dahomey. Paris: E. Larose.

Lloyd, Peter C. (1967). “Osifekunde of Ijebu.” In: P. Curtin, ed., Africa Remembered: Narratives by West Africans from the Era of the Slave Trade. Madison: University of Wisconsin Press, pp. 217-288.

Lovejoy, Henry B. (2013). "Redrawing Historical Maps of the Bight of Benin Hinterland, c. 1780." Canadian Journal of African Studies 47 (3), pp. 443-463.

Lovejoy, Henry B., dir. (accessed 2019). Liberated Africans. http://liberatedafricans.org. Lovejoy, Paul E. (2016). Jihād in West Africa during the Age of Revolutions. Athens: Ohio University Press.

Mabogunje, M.A., and Omer-Cooper, J. (1971). Owu in Yoruba History. Ibadan: Ibadan University Press. 
Martí-Henneberg, Jordi. (2011). "Geographical Information Systems and the Study of History." Journal of Interdisciplinary History 42 (1), pp. 1-13.

Mouléro, Thomas. (1965). Guézo ou Guédizo Massigbé. Etudes dahoméennes 4 (5), pp. 51-92.

Natural Earth. (Accessed 2014). http://www.naturalearthdata.com/downloads/.

Nunn, Nathan. (2008). "The Long-Term Effects of Africa's Slave Trades." The Quarterly Journal of Economics 13367, pp. 139-176.

Palmer, Mark. (2012). “Theorizing Indigital Geographic Information Networks.” Cartographica 47 (2), pp. 8o-91.

Parrinder, E.G. ([1956] 1967). The Story of Ketu: An Ancient Yoruba Kingdo. Ibadan: Ibadan University Press.

Sequeira, Sandra, Nunn, Nathan, and Qian, Nancy. (2017). "Migrants and the Making of America: The Short- and Long-Run Effects of Immigration during the Age of Mass Migration." CEPR Discussion Papers (2017), pp. 1-49.

Skupin, André, and Fabrikant, Sara Irina. (2003). "Spatialization Methods: A Cartographic Research Agenda for Non-geographic Information Visualization." Cartography and Geographic Information Science 30 (2), pp. 95-115.

Von Lünen, Alexander, and Travis, Charles, eds. (2013). History and GIs: Epistemologies, Considerations and Reflections. Dordrecht: Springer.

Zhang, Jingxiong, and Goodchild, Mike. (2002).Uncertainty in Geographical Information. New York: Taylor and Francis. 